Historic, archived document

Do not assume content reflects current scientific knowledge, policies, or practices. 



\section{Opportunities for Timber Management and Wood Utilization of the Mixed Conifer Type in Arizona and New Mexico}

David R. Betters

Dennis M. Donnelly

Harold E. Worth

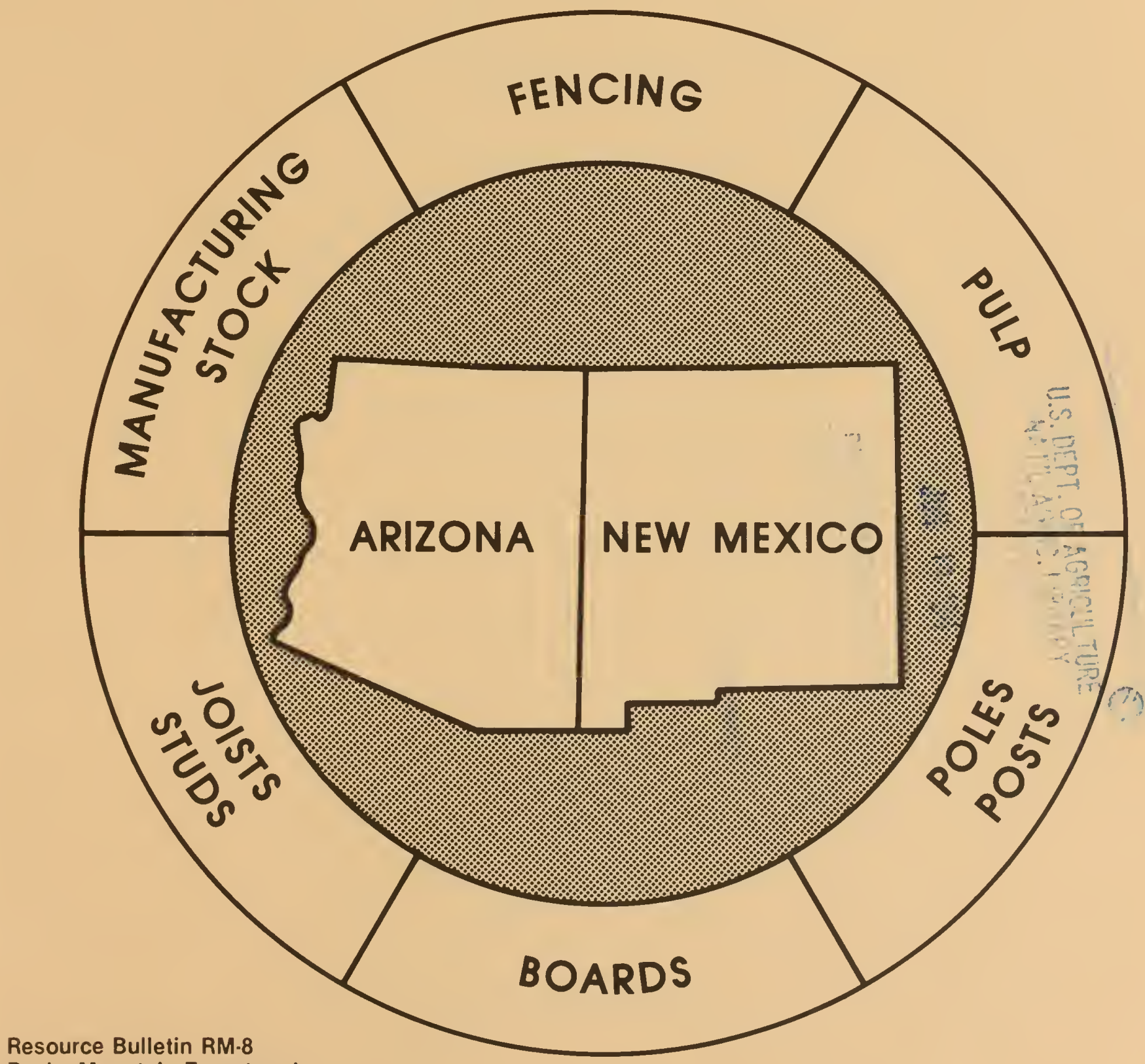

Resource Bulletin RM-8

Rocky Mountain Forest and

Range Experiment Station

Forest Service

U.S. Department of Agriculture 


\begin{abstract}
Production cost advantages favor Arizona mills, but marketing cost advantages favor New Mexico mills. Mills in both states can serve Chicago, Dallas, and Denver market areas with traditional and diverse new wood products. Forest management potential benefits from all increased utilization, resulting in better returns to the timber resource.
\end{abstract}

\title{
Acknowledgements
}

The authors thank the USDA Forest Service and Bureau of Indian Affairs personnel, individuals in the state forestry agencies, and mill operators who were contacted during the course of this study for their assistance and cooperation. They also acknowledge the help of W. Keith Kelso in gathering appropriate information and the efforts of Edward Odenwalder, Stephen Sherwood, Timothy Monahan, and Lyn Potter who helped analyze the data. 


\title{
Opportunities for Timber Management and Wood Utilization of the Mixed Conifer Type in Arizona and New Mexico ${ }^{1}$
}

\author{
David R. Betters, Professor \\ Colorado State University \\ Dennis M. Donnelly, Systems Analyst \\ and \\ Harold E. Worth, Principal, Market Analyst (Retired) \\ Rocky Mountain Forest and Range Experiment Station ${ }^{2}$
}

'This paper is based on a final report by David R. Betters, entitled "Opportunities for Increas. ing Harvest and Utilization of Mixed Conifers in Arizona and New Mexico." Unpublished report, Colorado State University, Department of Forest and Wood Sciences, Fort Collins, Colo., Rocky Mountain Forest and Range Experiment Station Cooperative Research Agreement 80-130-CA, $313 \mathrm{p}$. Further details are available in this report.

${ }^{2}$ Headquarters is in Fort Collins, in cooperation with Colorado State University. 


\section{CONTENTS}

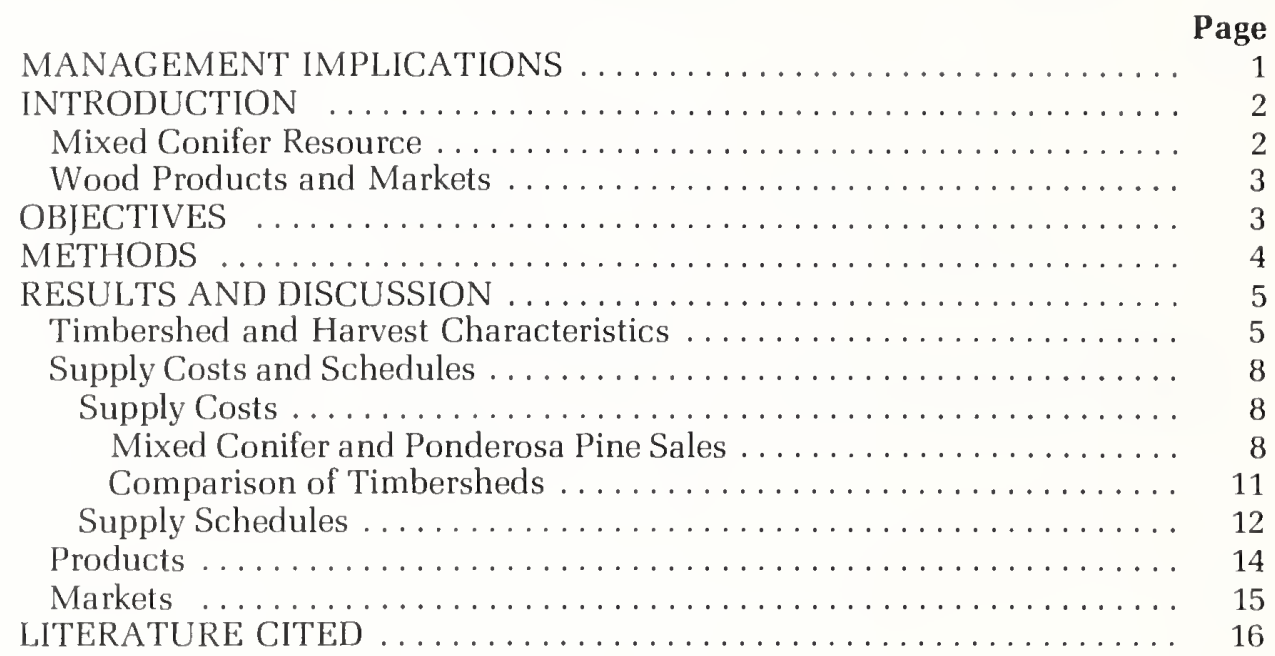




\title{
Opportunities for Timber Management and Wood Utilization of the Mixed Conifer Type in Arizona and New Mexico
}

\author{
David R. Betters, Dennis M. Donnelly, and Harold E. Worth
}

\section{MANAGEMENT IMPLICATIONS}

The structural lumber products now produced from mixed conifer forests generally have lower selling values (although not always less profit) than those produced from ponderosa pine. To help improve selling values, a more diverse set of products, for which the mixed conifer species are technically suited, might be manufactured with fairly low investment and production costs. This diversification has the potential to increase the overall selling value of mixed conifer logs, and at the same time, decrease the reliance now placed on the highly cyclical housing market, which contributes to depressed lumber prices over substantial periods of time. Successful development of such diversified product lines would require both aggressive marketing programs and careful mill production practices.

Selling values might be improved by shipping products to markets with the highest market prices and low transportation costs. Arizona and New Mexico processing centers have advantages because they are near to several of these prime market areas. They include the local in-state markets plus Chicago, Ill., Denver, Colo., and Dallas, Tex. Concentrating marketing efforts for traditional and new products in these market centers should help increase average selling values.

This study indicates that mixed conifer total production costs are generally the same as those for ponderosa pine within the same timbersheds. This is primarily a result of the mixed conifers' high volume per acre. However, the timber supply schedule, or cost per thousand board feet of logs delivered to the mill, is different for each timbershed largely because of the distribution of the timber and available road system. In the Eagar, Alamogordo, and Cuba timbersheds, mixed conifers are generally cheaper to procure than ponderosa pine; in Espanola and Albuquerque, the costs are about the same as ponderosa pine; and in Fredonia, mixed conifers are more expensive to procure. Both mixed conifer and ponderosa pine procurement costs are generally less for available volumes in the Arizona timbersheds; New Mexico timbersheds had higher procurement costs, which increased rapidly for additional volumes. The timbersheds ranked in order of overall procurement cost advantage for both ponderosa pine and mixed conifer are Fredonia, Eagar, Cuba/Espanola, Albuquerque/ Alamogordo.

Timbersheds with lower costs offer better economic support for intensive management programs applicable to substantial portions of the timbersheds. When pro- curement costs are lower, the difference between selling value and cost (less stumpage) is larger, creating the opportunity to better manage and utilize mixed conifer timber.

Arizona timbersheds have advantages compared to those in New Mexico, because the mixed conifer timber is larger, has fewer defects, is a large part of timbershed timber volume, and most of the mixed conifer land, as well as total timbershed area, and may be harvested with standard logging techniques. These characteristics combine to make the Arizona wood utilization situation more favorable from a timber resource standpoint.

In northern New Mexico timbersheds, marginal land is prevalent (almost $50 \%$ of the CFL) with $10 \%$ to $35 \%$ of it occupied by mixed conifers. Therefore, expanding the harvest of mixed conifers would involve some logging on marginal land, using more expensive cable logging systems. Several incentives that could help mitigate the high costs of cable logging are (1) offering significant timber volumes in the sales and providing this volume over extended periods of time; (2) combining, where possible, cable logging with conventional logging; (3) applying cable systems only to areas with high volumes per acre and short logging distances; and (4) allowing a larger margin for profit and risk. Certain of these incentives are now being applied to timber sale offerings in the two states. Additionally, the advantages in terms of procurement costs and volumes available in certain zones within timbersheds could be used to identify the most economical areas for applying cable logging.

Actual timber harvest in most timbersheds has been declining but is still very close to the programmed cut in most timbersheds. Maintaining the present harvest level and, in particular, expanding this harvest to a potential yield level, would require production of diversified product lines which utilize smaller diameter materials. This is because realization of potential yield harvests would necessitate silvicultural treatments that include thinning, shelterwood, and selection methods. These methods usually result in some of the timber removed being smaller or of poorer quality. The Eagar timbershed, with the nearby pulpmill, now has the capability of handling smaller materials. Other processing centers could expand their capabilities along these lines by considering some of the new products mentioned later. Additionally, where timbersheds are near major population centers, such as the New Mexico timbersheds, fuelwood cutting by the public might help increase utilization of smaller-size timber and logging residues and help accomplish intensive timber management goals. 
From a resource standpoint, the northern New Mexico timbersheds have the largest capability to increase harvest. In those timbersheds, the potential yield capability of federal and Indian lands is eight times more than the current programmed cut. Further, there is much state and private land in northern New Mexico which might add to this harvest availability. The possible harvest increase in other timbersheds is lower, primarily because they have less marginal land. Fredonia's annual harvest could increase by $50 \%$ and Alamogordo's $130 \%$ under a potential yield program. In all timbersheds, this level of management would allow for considerably expanded mill capacity, particularly in northern New Mexico. On the average, annual mill capacity could be increased by 15 to 30 million board feet at each processing center. The opportunities for expanded wood utilization are great, but only if mills diversify their production.

From a productivity standpoint, resource managers can increase forest growth considerably by intensive management of mixed conifer lands. From a timber investment standpoint, mixed conifer lands should offer a very cost efficient investment.

\section{INTRODUCTION}

Mixed conifer forests in Arizona and New Mexico provide many benefits that are based on timber, wildlife, water yield, range, and recreation. Increased production of such benefits relies, at least in part, on the ability to apply vegetation management practices that are economically justified. This in turn, usually requires economical use of the raw material as wood products. Within the two states, ponderosa pine is the predomi- nant species utilized for wood products. Finding economic outlets for the timber is often more difficult when using mixed conifer species.

Compared to ponderosa pine, mixed conifer logs often have a higher level of defect and typically sell for lower prices. Sometimes logs are small and must be harvested on steep slopes. These problems tend to increase costs and decrease profit margins. Therefore, the wood utilization and marketing aspects of mixed conifer management should be analyzed for specific locations.

\section{MIXED CONIFER RESOURCE}

Mixed conifer forests typically contain Douglas fir (Pseudotsuga menziesii var. glauca), ponderosa pine (Pinus ponderosa and Pinus ponderosa var. arizonica), white fir (Abies concolor), Engelmann spruce (Picea engelmannii), aspen (Populus tremuloides), southwestern white pine (Pinus strobiformis), blue spruce (Picea pungens), and corkbark fir (Abies lasiocarpa and Abies lasiocarpa var. arizonica), often in that order of abundance. In some mixed conifer areas in the Southwest, one or more of these species may be absent (Jones 1974, Moir and Ludwig 1979).

Mixed conifer stands are scattered throughout the mountains of both Arizona and New Mexico, but are most extensive in the White Mountains and Mogollon and North Kaibab Plateaus in northcentral and mideastern Arizona, and the Sacramento, Sangre de Cristo, and Zuni mountains of southeastern and northcentral New Mexico (Moir and Ludwig 1979). Figure 1 illustrates the location of the mixed conifer forests in the two states.

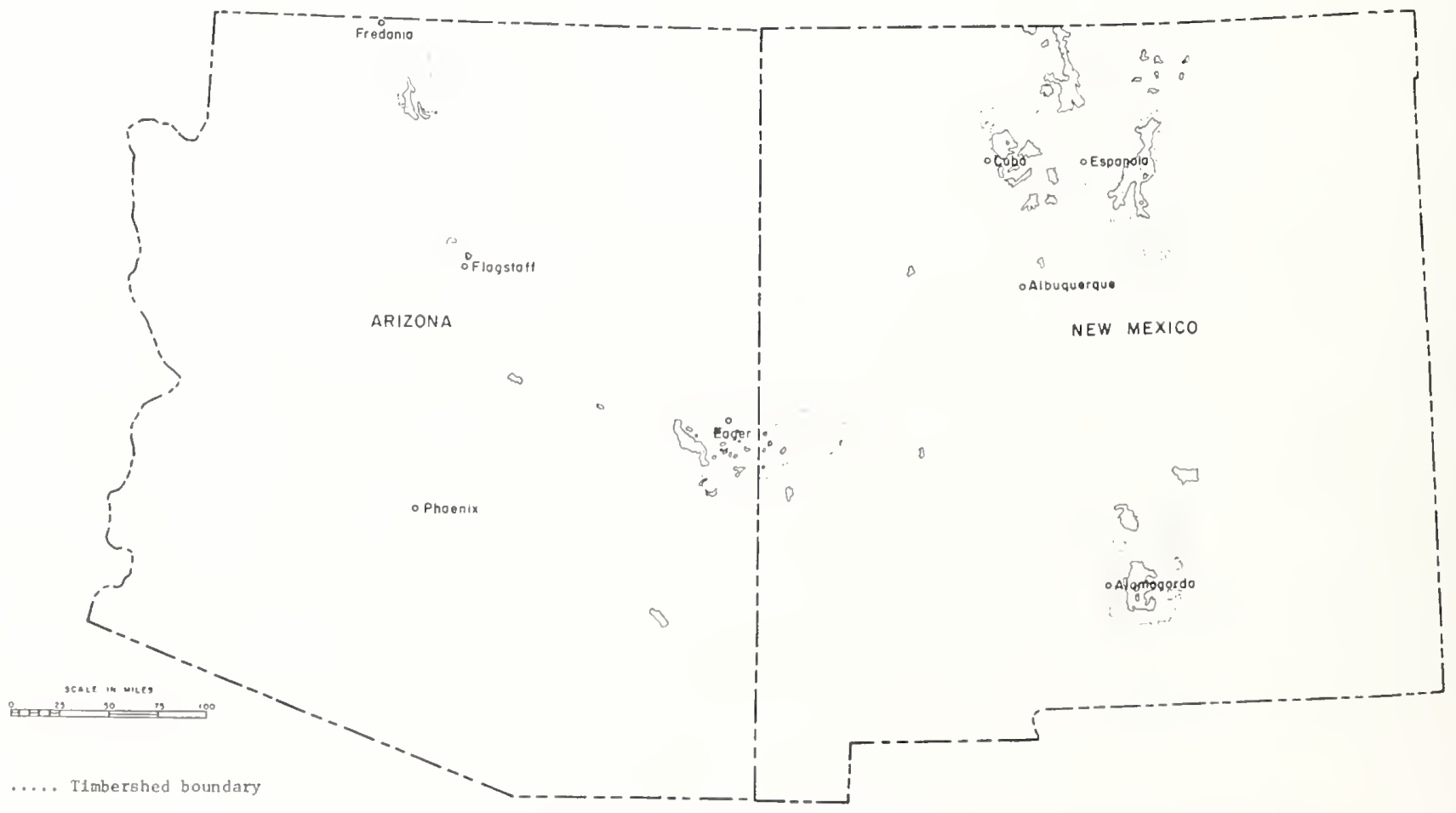

Figure 1-The mixed conifer type, processing centers, and timbershed boundary locations in Arizona and New Mexico. 
This forest type is typically found between the ponderosa pine and spruce-fir types, at elevations of 8,000 to 10,000 feet. Because the stands are at higher elevations, they tend to receive more moisture, a critical growth factor in the Southwest. This additional moisture makes most mixed conifer sites more productive with a higher timber site index than for ponderosa pine.

Most mixed conifer forests are located on public or Indian ownerships. In Arizona, virtually all the mixed conifers are on either national forest land, in particular the Kaibab and Apache National Forests, or the White River Apache Reservation. In New Mexico, the mixed conifer type is principally on the Lincoln, Carson, and Santa Fe National Forests, and the Mescalero Apache Indian Reservation. Additionally, there are some mixed conifer stands on state and private lands in the northcentral part of the state.

Mixed conifers, excluding ponderosa pine, make up a larger portion of New Mexico's commercial timber volume than Arizona's - 37\% compared to $18 \%$ (Green and Setzer 1974). Both states have fairly large areas of sawtimber-sized mixed conifers. In Arizona, about 97\% of 309,000 acres of commercial forest land is sawtimber size. In New Mexico, about $86 \%$ of $1,667,000$ acres of commercial forest land is classed as sawtimber (Green and Setzer 1974).

Most silvicultural prescriptions use the shelterwood or selection systems. Regionally, prescriptions often vary, because mixed conifers exhibit many different stand structures (Jones 1974) and have a variety of problems caused by insect, disease (particularly dwarf mistletoe), and windthrow. This variability in stands often results in a great deal of diversity in timber volume, size, and mix of species harvested.

\section{WOOD PRODUCTS AND MARKETS}

The wood products industry was one of the first established in the Southwest and continued to grow with the region until its production and employment peaked in the early 1960's (Setzer and Barrett 1977, Setzer and Throssell 1977). Since then, the number of wood product firms, employment, and lumber production have declined.

In the years after 1970, lumber production averaged $340 \mathrm{mmbf}$ per year in Arizona and $250 \mathrm{mmbf}$ per year in New Mexico (Western Wood Products Association 1980). The bulk of this lumber is produced by five fairly large firms - three in New Mexico and two in Arizona - whose mills are equipped with debarkers, bandsaws, gang saws, edgers, chippers, dry kilns, and planers. Most of these firms' mills are capable of producing at least $20 \mathrm{mmbf}$ of graded lumber per year.

A pulp and paper mill in Snowflake, Ariz., produces newsprint and liner board (412 $\mathrm{M}$ tons per year), while in Albuquerque, N.Mex., an industrial particleboard plant has capacity of 42 million square feet per year. (Wood Industry of New Mexico 1979, Primary Wood Industries of Arizona 1978).

Sawmills in the two states share many characteristics but also exhibit several differences. Both Arizona's and New Mexico's sawmills are highly dependent on federal timber as a source of raw materials. Arizona and New Mexico sawmills obtain about $99 \%$ and $82 \%$, respectively, of their timber from federal lands. ${ }^{3}$ In other western states (excluding the West Coast), an average of only $74 \%$ of the timber harvest comes from federal sources.

New Mexico's sawmills use more mixed conifer species than Arizona's. Mixed conifer species comprise $35 \%$ of New Mexico's harvest compared to 13\% of Arizona's. In both states, however, the bulk of each state's harvest is ponderosa pine (Western Wood Products Association 1980).

Mixed conifer species are most often the raw material for dimension stock. Ponderosa pine typically is sawn for shop and graded board lumber. Mills manufacture studs from both species groups. A few of the larger mills, and most of the smaller operations, produce one or more other products, including rough lumber, timbers, ties, viga poles, ${ }^{4}$ fence post and poles, fuelwood, and houselogs. However, the total production of these products is small compared to that of graded lumber (Western Wood Products Association 1980). By-products, such as chips and sawdust, are normally sent to the pulp and paper mill, a particleboard plant (when economically feasible), or are burned at the sawmill to provide heat for the kilns.

Arizona mills market their products in other western states and in the Midwest. New Mexico's mills market to other western states and the southcentral states of Texas and Oklahoma. About $50 \%$ of the lumber is distributed through wholesalers, and another $30 \%$ is distributed directly to retailers. About $90 \%$ of the Arizona/New Mexico lumber is shipped by truck compared to an average of $65 \%$ for western sawmills in general. This is partly a result of the large "local" demand in nearby western and south central states. The relatively small volume of products shipped by rail is more economical when distance is greater than 900-1,000 miles one way.

\section{OBJECTIVES}

Because the forest products industry in the Southwest is oriented to lumber, only certain species and sizes of trees are sought for primary products. Mixed conifer forests, however, potentially may supply a wide variety of tree species and sizes. The goal then is to better match the types and kinds of wood fiber produced by forest management with wood products that southwestern forest products industry currently produces and other products that it could produce.

This study examines the economic and marketing aspects of the interaction between forest management

\footnotetext{
${ }^{3}$ These figures are from the Western Wood Products Association Statistical Yearbook. The statistics include lands administered under the Bureau of Indian Affairs (BIA). Management and timber harvests on BIA lands are controlled by the respective Indian tribe, not the federal government.
}

"Viga poles are the roof joists employed in adobe style, southwestern Spanish American architecture. Viga poles may be decorative, functional, or both. 
and forest industry. It focuses on specific timbersheds and their associated wood products mills. The objectives of this study are:

1. to examine the mixed conifer timber supply with respect to quantity and location,

2. to determine the economic availability of the mixed conifer timber supply as it relates to timber size, product type, and harvest costs,

3. to identify the most promising markets for mixed conifer products from specific timbersheds and their associated mills.

\section{METHODS}

The first step in the analysis is to choose the location of processing centers. Locations considered for processing centers must be within 100 miles of mixed conifer forests and have an existing mill production capacity of at least $20 \mathrm{mmbf}$ per year. ${ }^{5}$ Because Fredonia and Eagar, Arizona, and Alamogordo, Albuquerque, Cuba and Espanola, N. Mex., match these criteria, they are the six processing centers analyzed in this study (fig. 1).

Because topographic features and transportation systems vary by location, each processing center has a unique wood procurement area or timbershed. Personnel from national forests, the Bureau of Indian Affairs, and mills helped establish the boundaries for each processing center's timbershed. The criteria used to establish boundaries included past procurement activities and the quantity of timber likely to be economically available in the foreseeable future. While the boundaries were selected to represent economic operating conditions, every effort was made to use boundaries compatible with existing inventory data, thus avoiding extrapolation or adjustment error. Finally, timbershed boundaries for certain processing centers overlapped. The areas were documented where overlap occurs, but each processing center was analyzed as a separate case study. Overlap between processing center timbersheds was especially noticeable in the north-central New Mexico area.

USDA Forest Service timber management plans and forest survey publications provided data concerning timber characteristics in each timbershed. Local resource managers familiar with each processing center and its associated timbershed helped to verify and expand the data. Timber resource information collected for each timbershed included the location and characteristics of the timber, both mixed conifer and other timber types, and past and present, actual and planned levels of harvest. This information was summarized in tables, and the locations of timber types were recorrled and overlayed on U.S. Geological Survey state maps. In cases where the inventory and harvest data represented sites outside the timbershed area, the infor-

${ }^{5}$ Certain Indian-owned mills satisfied these two criteria, but used only tribal timber as a source of timber supply. These mills were not considered as processing centers in this study. Further, mills that procured a large portion of their raw material outside the two states andlor actually operated at a much lower production level also were not considered. mation was adjusted to fit the timbershed boundaries by prorating the figure based on that area applicable to the timbershed.

USDA Forest Service timber sale appraisal summaries furnished information for each timbershed about cost and other characteristics of recent timber sales. Most timber sale data are from the previous 5 years; but, in some instances, data from the past 7-8 years are included to develop an adequate sample size for both mixed conifer and ponderosa pine sales. All cost figures were adjusted to a common base year; then descriptive statistics were developed for each category of cost (e.g., logging) in the appraisal. A statistical " $t$ " test helped determine if there were significant differences between various characteristics of mixed conifer and ponderosa pine sales within the timbershed. Two other statistical tests, a one-way analysis of variance and Tukey's multiple comparison, helped determine if there were significant differences in various cost categories between timbersheds.

Economic supply schedules for logs delivered to the mill deck were developed for mixed conifer, ponderosa pine, and the aggregate of the two, within each timbershed. The supply schedules constructed relate cost per unit volume and distance. Using the cost information for that timbershed, an average total procurement cost per thousand board feet, less hauling, roads and stumpage, was estimated for mixed conifer and ponderosa pine. ${ }^{6}$ The types of roads encountered within a given distance from the mill affected estimates of hauling cost. On this basis, a hauling cost per thousand board feet was calculated for each 10-mile increment from the processing center. The volume of mixed conifer and ponderosa pine within that distance zone was estimated using the U.S. Geological Survey maps overlaid with the location of the timber types. A planimeter was used to estimate acreages within each distance zone; then a volume figure was derived for each timber type using the proportion that acreage represented of the total accessible or operable volumelacreage for the timbershed.

Once costs are well defined, the difference between wholesale lumber prices at the market and freight costs to the market will determine the most profitable market locations for each processing center. The larger the difference, the more profitable it would be to market the product in that area. Seven major market centers were selected for analysis. These markets are close to the Southwest and are considered economically feasible possibilities. An informal telephone inquiry provided estimates of wholesale lumber prices in these markets. Truck freight rates published by the Western Wood Products Association provided the basis to estimate freight costs from each processing center to each market area.

In order to identify potential new products manufactured from mixed conifer timber, a technical evaluation

\footnotetext{
${ }^{6}$ Road costs were not included, because they were extremely variable depending on the sale conditions. Stumpage was not in. cluded, because it is a function of the other costs. The appraisal process calculates stumpage as a residual value, or what is left after costs and a margin for profit and risk are subtracted from lumber selling value.
} 
matched properties important for particular wood products with corresponding properties of mixed conifers. Most of the information for this evaluation came from published technical sources, but discussions with mill operators also provided suggestions for new products.

\section{RESULTS AND DISCUSSION}

\section{TIMBERSHED AND HARVEST CHARACTERISTICS}

Table 1 describes each timbershed's timber supply characteristics and reveals some differences as well as similarities between timbersheds. Timbersheds varied in their amount of commercial forest land (CFL), with northern New Mexico timbersheds having the largest acreages and Fredonia, Ariz. the smallest. However, the northern New Mexico timbersheds also have significant amounts of marginal component lands in the CFL base. If these lands are deleted and the standard or operable component acres are the only acres considered, there is much less variation among timbersheds. Thus, the operable acres, or acres available for harvest by conventional logging means, is reasonably the same in each timbershed.

In most timbersheds, the mixed conifer acreage ranges from $10 \%$ to $35 \%$ of the total marginal component acres. Only the Alamogordo timbershed and the Fredonia timbershed have a larger proportion of mixed conifer type on marginal lands. However, in both cases, the total marginal component acreage is rather small compared to the timbershed's total commercial forest land, and the majority of the mixed conifer acreage is located in the standard component.

Because most marginal component lands are on steep slopes, harvesting these acres normally requires cable logging, which costs more. Thus, increased harvest and utilization of mixed conifer and other timber types from marginal lands will require efficient use of cable logging systems. This is especially the case in northern New Mexico. Although cable systems are more expensive, the timber located on marginal component land is generally larger and has more volume per acre, particularly if it is mixed conifer. This can help to offset the higher costs; and if cable logging is combined with conventional logging sales, the mix can provide an economically viable harvest. This "sale mix" concept is now being applied in the Alamogordo and Eagar timbersheds.

Generally, the mixed conifer type makes up about $30 \%$ to $40 \%$ of the standard or operable sawtimber acreage and volume, respectively, in each timbershed. The only exception to this is Alamogordo, where approximately $50 \%$ and $70 \%$, respectively, of the timbershed acreage and volume is comprised of mixed conifer. Ideally (with proper road and stand conditions), forest management would require the timber types harvested in each timbershed to be proportional to these figures. This is now the case in the Eagar and Alamogordo timbersheds-the proportion of species cut is close to the proportion of species available for harvest-but the remaining timbersheds should have a slightly higher portion of mixed conifer species in the harvest cut. In these other timbersheds about 15-25\% of the present harvest is species other than ponderosa pine; this should probably be increased by about $10 \%$ to have the species cut correspond to available acreage and volumes of mixed conifer.

In all timbersheds, a large portion, averaging $45 \%$, of the mixed conifer type is classed as Site I land (60 cubic feet or greater growth per acre per year). This percentage of productive land is normally greater than the mixed conifer type's percentage of total timbershed acreage. For example, in Fredonia the mixed conifer type represents $40 \%$ of the timbershed acres but more than $60 \%$ of the Site I acres; in Alamogordo it is $46 \%$ and $77 \%$, respectively, of the timbershed and Site I acres. In other timbersheds, the differences in percentages are somewhat less, but only because those timbersheds have some spruce-fir acres that also tend to have higher site indices. Intensive timber management programs are likely to concentrate on more productive sites. This implies a larger portion of these treatments should be considered for mixed conifer sites.

The mixed conifer type is located in fairly large, continuous blocks in the Cuba, Alamogordo, and Fredonia timbersheds; whereas in the Albuquerque, Espanola and, especially, Eagar timbersheds, the acreage is scattered in blocks throughout the area. Blocks of mixed conifer are located fairly close to the Cuba processing center; at mid-distance in the timbershed tributary to Alamogordo; and more distance in the case of the Fredonia processing center. In the other timbersheds, as mentioned previously, the blocks of mixed conifer are in different subregions within the timbershed; and, therefore, distances vary from processing centers. Those differences make mixed conifer procurement, or hauling costs, vary depending on the timbershed.

All processing centers are heavily dependent on Forest Service timber. The only processing center not $90-100 \%$ dependent on Forest Service timber is Alamogordo, where approximately $50 \%$ of the harvest comes from the Mescalero Apache Indian Reservation; most of the remainder comes from the Forest Service lands. State and private lands generally have not been available for harvest in the recent past, although they represent a fairly large portion of acreage in the New Mexico timbersheds. Most private ownerships are small with traditionally heavy emphasis on recreational use, which is likely to continue. However, the extent of private acreage within New Mexico timbersheds indicates the potential for expanded harvest, if private landowners could be encouraged to manage their lands for multiple products, including recreation and timber.

In most cases, actual timber harvest is very close to the programmed cut (table 1). Fredonia is an exception. Although actual cut has been increasing in that timbershed, there appears to be an opportunity to expand the actual harvest by 8 million board feet per year in order to meet annual programmed harvest. In most timbersheds, the actual cut has declined slightly over the past 10 years. This is probably a result of general economic conditions and the weak housing market, rather than a 
Table 1.-Timbershed characteristics'

\begin{tabular}{|c|c|c|c|c|c|c|}
\hline & $\begin{array}{l}\text { Fredonia } \\
\text { Ariz. }\end{array}$ & $\begin{array}{l}\text { Eagar } \\
\text { Ariz. }\end{array}$ & $\begin{array}{l}\text { Alamogordo } 2 \\
\text { N. Mex. }\end{array}$ & $\begin{array}{l}\text { Cuba }^{3} \\
\text { N. Mex. }\end{array}$ & $\begin{array}{l}\text { Espanola } \\
\text { N. Mex. }\end{array}$ & $\begin{array}{l}\text { Albuquerque } \\
\text { N. Mex. }\end{array}$ \\
\hline $\begin{array}{l}\text { Total timbershed area (thousand } \\
\text { acres, commercial forest land }{ }^{5} \text { ) }\end{array}$ & 298.2 & 624.6 & $\begin{array}{l}218.7 \\
172.0(\mathrm{BIA})\end{array}$ & 493.0 & 819.0 & 1138.0 \\
\hline $\begin{array}{l}\text { Land class }{ }^{6} \text { (thousand acres) } \\
\text { USFS }\end{array}$ & & & & & & \\
\hline $\begin{array}{l}\text { Standard } \\
\text { Special } \\
\text { Marginal } \\
\text { State and private } \\
\text { BIA }\end{array}$ & $\begin{array}{r}273.0 \\
18.0 \\
7.2 \\
0.3 \\
0.0\end{array}$ & $\begin{array}{c}520.7 \\
18.9 \\
86.1 \\
\text { N/A } \\
0.0\end{array}$ & $\begin{array}{r}206.8 \\
0.0 \\
11.9 \\
99.0 \\
172.0\end{array}$ & $\begin{array}{r}248.0 \\
41.0 \\
212.7 \\
293.4 \\
0.0\end{array}$ & $\begin{array}{r}343.4 \\
46.7 \\
317.5 \\
293.4 \\
0.0\end{array}$ & $\begin{array}{r}450.4 \\
73.7 \\
457.2 \\
82.8 \\
0.0\end{array}$ \\
\hline $\begin{array}{l}\text { Timber type }{ }^{7} \text { (thousand acres) } \\
\text { Ponderosa pine } \\
\text { Mixed conifer } \\
\text { Spruce-fir } \\
\text { Aspen }\end{array}$ & $\begin{array}{r}198.0 \\
82.8 \\
0.0 \\
14.0\end{array}$ & $\begin{array}{r}446.1 \\
77.5 \\
5.9 \\
10.3\end{array}$ & $\begin{array}{r}61.5 \\
104.1 \\
1.7 \\
8.0\end{array}$ & $\begin{array}{r}127.0 \\
43.8 \\
8.0 \\
\text { N/A }\end{array}$ & $\begin{array}{c}182.7^{\prime} \\
119.8 \\
68.0 \\
\text { N/A }\end{array}$ & $\begin{array}{c}242.7 \\
159.8 \\
75.0 \\
\text { N/A }\end{array}$ \\
\hline $\begin{array}{l}\text { Timber volumes }{ }^{\circledR} \text { (mmbf) } \\
\text { Sawtimber } \\
\text { Ponderosa pine } \\
\text { Mixed conifer } \\
\text { Spruce-fir } \\
\text { Aspen } \\
\text { Total }\end{array}$ & $\begin{array}{c}438.2 \\
237.3 \\
0.0 \\
\text { N/A } \\
676.5\end{array}$ & $\begin{array}{r}1658.6 \\
881.6 \\
42.1 \\
159.9 \\
2742.2\end{array}$ & $\begin{array}{r}144.4 \\
789.1 \\
63.1 \\
84.8 \\
1081.4\end{array}$ & $\begin{array}{c}521.4 \\
167.7 \\
46.4 \\
\text { N/A } \\
735.5\end{array}$ & $\begin{array}{c}502.4 \\
466.7 \\
394.4 \\
\text { N/A } \\
1492.7\end{array}$ & $\begin{array}{c}800.4 \\
602.7 \\
435.4 \\
\text { N/A } \\
1867.7\end{array}$ \\
\hline $\begin{array}{l}\text { Timber harvest }{ }^{9} \\
\text { Actual cut (mmbf/yr.), average } \\
\text { of cut } 1975-80 \text {, average } \\
\text { change } 1970-80\end{array}$ & $43.0,0.8$ & $55.0,-4.9$ & $\begin{array}{l}10.8,-0.1 \\
18.4,-2.9 \quad(\mathrm{BIA})\end{array}$ & $26.7,-2.0$ & $36.0,-1.2$ & $53.6,-1.9$ \\
\hline Programmed cut (mmbf/yr.) & 51.0 & 55.0 & $\begin{array}{l}15.0 \\
18.0(\mathrm{~B} \mid \mathrm{A})\end{array}$ & 27.5 & 36.8 & 54.8 \\
\hline $\begin{array}{l}\text { Potential yield (mmbf/yr.) } \\
\text { Fuelwood (thousand cords/yr.) } \\
\text { average } 1975-80, \text { average } \\
\text { change } 1975-80\end{array}$ & 80.0 & 55.0 & 35.0 & 251.3 & 290.5 & 447.5 \\
\hline $\begin{array}{l}\text { Commercial } \\
\text { Free use/nominal fee }\end{array}$ & $\begin{array}{ll}0.22, & 0.01 \\
2.2, & 0.77\end{array}$ & $\begin{array}{ll}5.1, & 0.95 \\
0.02, & 0.02\end{array}$ & $\begin{array}{l}1.0,0.09 \\
10.2,0.90 \\
1.7,0.18(\mathrm{BIA})\end{array}$ & $\begin{array}{c}5.8, \mathrm{~N} / \mathrm{A} \\
17.0,-2.0\end{array}$ & $\begin{array}{c}4.6, \text { N/A } \\
24.4,-0.71\end{array}$ & $\begin{array}{c}8.5, \mathrm{~N} / \mathrm{A} \\
37.8,-1.37\end{array}$ \\
\hline $\begin{array}{l}\text { Processing capacity } \\
\text { Site class }{ }^{10} \text { (thousand acres, } \\
\text { percentage of class) }\end{array}$ & 35.0 & 50.0 & 20.0 & 25.0 & 25.0 & 20.0 \\
\hline $\begin{array}{l}\text { Site I } \\
\text { Ponderosa pine } \\
\text { Mixed conifer } \\
\text { Spruce-fir } \\
\text { Aspen }\end{array}$ & $\begin{array}{r}27.2,37 \% \\
44.8,61 \% \\
0.0, \quad 0 \% \\
1.5, \quad 2 \%\end{array}$ & $\begin{array}{r}80.9,51 \% \\
60.7,38 \% \\
4.0, \quad 3 \% \\
13.4, \quad 8 \%\end{array}$ & $\begin{array}{r}11.3,15 \% \\
58.4,77 \% \\
1.9,2 \% \\
4.3,6 \%\end{array}$ & $\begin{array}{l}17.4,6 \% \\
41.8,30 \% \\
25.2,71 \% \\
\text { N/A }\end{array}$ & $\begin{array}{l}23.3,6 \% \\
69.5,30 \% \\
39.2,71 \% \\
\text { N/A }\end{array}$ & $\begin{array}{l}33.8,6 \% \\
96.9,30 \% \\
105.7,71 \% \\
\text { N } / A\end{array}$ \\
\hline $\begin{array}{l}\text { Site II } \\
\text { Ponderosa pine } \\
\text { Mixed conifer } \\
\text { Spruce-fir } \\
\text { Aspen }\end{array}$ & $\begin{array}{r}27.2,37 \% \\
26.8,15 \% \\
0.0, \quad 0 \% \\
5.4, \quad 3 \%\end{array}$ & $\begin{array}{r}323.9,88 \% \\
39.9,11 \% \\
21.0,0.5 \% \\
1.7,0.5 \%\end{array}$ & $\begin{array}{r}42.6,45 \% \\
46.1,49 \% \\
0.9, \quad 1 \% \\
4.3, \quad 5 \%\end{array}$ & $\begin{array}{c}43.6,15 \% \\
51.4,37 \% \\
8.2,23 \% \\
\text { N/A }\end{array}$ & $\begin{array}{c}55.7,15 \% \\
85.7,37 \% \\
28.8,23 \% \\
\text { N/A }\end{array}$ & $\begin{array}{r}84.5,15 \% \\
119.6,37 \% \\
34.2,23 \% \\
\text { N/A }\end{array}$ \\
\hline $\begin{array}{l}\text { Site III } \\
\text { Ponderosa pine } \\
\text { Mixed conifer } \\
\text { Spruce-fir } \\
\text { Aspen }\end{array}$ & $\begin{array}{r}22.6,53 \% \\
11.5,27 \% \\
0.0, \quad 0 \% \\
8.5,20 \%\end{array}$ & $\begin{array}{c}96.4,91 \% \\
10.0,9 \% \\
\text { N/A } \\
\text { N/A }\end{array}$ & $\begin{array}{c}38.4,86 \% \\
6.3,14 \% \\
\text { N/A } \\
\text { N/A }\end{array}$ & $\begin{array}{c}22.9,79 \% \\
45.9,33 \% \\
2.1, \quad 6 \% \\
\text { N/A }\end{array}$ & $\begin{array}{l}293.4,79 \% \\
76.5,23 \% \\
7.6,6 \% \\
\text { NIA }\end{array}$ & $\begin{array}{l}445.0,79 \% \\
106.7,23 \% \\
9.0,6 \% \\
\text { NIA }\end{array}$ \\
\hline
\end{tabular}


'More detailed information is available in the Final Report, Opportunities for Increasing Harvest and Utilization of Mixed Conifers in Arizona and New Mexico, Cooperative Study, RM Agreement No. 80-130-CA, 1981. 313 p.

${ }^{2}$ All figures are for the Lincoln National Forest unless otherwise noted as BIA. Because the timber management plan for the Mescalero Apache Indian Reservation was not available, detailed volume information is not shown for BIA lands. However, on-site discussions with BIA officials indicated the Reservation's timber is about one-half mixed conifer and one-half ponderosa pine.

${ }^{3}$ Figures for the Cuba, Espanola, and Albuquerque timbersheds were estimated based on the portion of total Carson and Santa Fe National Forest acreage located in that timbershed. State and private CFL acreage figures for Cuba and Espanola are for Taos and Rio Arriba counties; Albuquerque includes Bernalillo, Sandoval, and Torrance counties. State and private figures are not included in volume available, because very little harvesting occurs on these lands. The Cuba timbershed contains 118,000 CFL acres it shares with Albuquerque; the Albuquerque timbershed contains 160,000 CFL acres that it shares with Cuba, and also contains 278,000 CFL acres it shares with Espanola; in addition, the Cuba timbershed also contains 160,000 CFL acres it shares with both Albuquerque and Espanola.

'Percentages for Sites I, II, and III for Carson National Forest were not available. Percentages for Santa Fe National Forest were used in the calculation. The acreage figures in each site index are based on total CFL acres.

${ }^{5}$ Commercial forest land (CFL) is that forested land capable of producing growth of at least 20 cubic feet per acre per year.

${ }^{6}$ Standard component lands are that portion of U.S. Forest Service CFL lands that are suitable and available for timber production and can be harvested under the usual provisions of a timber sale contract. Special component lands are that part of the U.S. Forest Service CFL that are suitable and available for timber production but require specially designed silvicultural treatments to achieve other key resource objectives. Marginal lands are USDA Forest Service CFL lands that are suitable for timber production but not currently available because of constraints associated with costs, product values, lack of market or resource needs. State and private lands are forested lands in those ownerships which fit the definition of CFL.

'Timber type class is based on the dominant tree species; if the species makes up more than $50 \%$ of the volume, the site is classed as that type. Mixed conifer have no one species that makes up 50\% of the stand volume, and many of these have ponderosa pine in them. These are operable or standard component acres.

${ }^{8}$ Sawtimber are trees 9 inches d.b.h. and larger and volumes are calculated to a variable top diameter inside bark. Information concerning poletimber volumes are generally not available. NIA indicates the data are not available. These are operable or standard component acres.

${ }^{9}$ Actual cut is the actual amount of timber cut during a year. Programmed cut or harvest is the scheduled volume available for harvest in a fiscal year; it is based on potential yield considerations, funding and markets. Potential yield is the long-term sustainable harvest of the forest under a regulated management plan. The programmed harvest for Alamogordo is the combination of USFS and BIA allowable cuts; for Cuba, Espanola and Albuquerque, it involves a proration based on timbershed size and the Santa Fe and Carson National Forest harvest figures.

${ }^{10}$ Site Class I lands are capable of tree heights of 80 feet in 100 years or growth of 60 cubic feet per acre per year or greater; Site $1 / 40$ to 79 feet in height in 100 years or 40-60 cubic feet per acre per year; Site III less than 40 feet in height in 100 years or less than 40 cubic feet per acre per year. Figures for Eagar include some CFL acreage outside the timbershed.

reduction in available timber. Overall, there seems to be adequate capacity existing in processing centers to handle the present programmed harvest.

Potential yield varies considerably by timbershed, with the greatest opportunities for expanding harvest being in the northern New Mexico and Fredonia timbersheds (table 1). The northern New Mexico timbersheds, for example, could potentially harvest eight times more timber than programmed in the current cut. Attaining such harvest levels would require logging large acreages of marginal component lands and cutting smallersized material as part of a timbershed-wide intensive timber management program. Cable logging and increased utilization capacity capable of handling smaller-sized materials would be necessary.

Fredonia and Alamogordo have potential for increasing timber harvest by $60 \%$ and $130 \%$, respectively, over the current programmed cut. These potential increases are less than those possible in the northern New Mexico timbersheds, because Fredonia and Alamogordo have substantially less marginal component lands. Most national forest lands in these timbersheds are standard or operable acreages. However, a potential yield program implemented in these timbersheds would require additional mill capacity ( 30 million board feet at Fredonia and 15 million board feet at Alamogordo) as well as the capability to handle smaller material.

Eagar is the only timbershed where programmed harvest is close to potential yield. Currently, the pulpwood market (Colorado Plateau Contract) in the Eagar timbershed area allows removal of smaller-sized material, resulting in more intensive timber management. In addition, there is some marginal component land which could, via cable logging, allow a further increase in the harvest level.

Compared to other timbersheds, commercial and individual fuelwood harvest is much greater in New Mexico. In northern New Mexico, a fairly large number of "locally dependent" communities burn wood as a major alternative heat source. Additionally, there are commercial markets at winter ski areas and large population centers in the west Texas and Albuquerque, N. Mex. regions. Eagar and Fredonia have less fuelwood use, because the areas are fairly isolated and are some distance from major population centers. However, they also have experienced an increase in fuelwood harvest, which is likely to continue in the future, if fossil fuel prices remain at high levels compared to wood.

The area's national forests require permits for commercial and private cutting of fuelwood. Generally, the fuelwood is harvested from dead and downed material or from logging residues. In areas where a substantial fuelwood market exists, timber management/utilization might be improved by cutting 6-inch to 9-inch live timber for fuelwood as part of commercial thinning operations.

'The new national forest management plans were in the process of being completed at the time of this study, and the impact these plans would have on the level of harvests, both programmed and potential yield, was not known. 


\section{SUPPLY COSTS AND SCHEDULES}

\section{Supply Costs}

Table 2 contains the results of the statistical analysis of each timbershed's timber sale appraisal data. The left side of the table shows, by timbershed, the mean or average values of various sale characteristics for both mixed conifer and ponderosa pine sales and a combined average for all sales. The right side illustrates the range in values for these same characteristics (for all sales combined) and indicates the results of a statistical analysis that tests for significant differences in the characteristics between timbersheds.

\section{Mixed Conifer and Ponderosa Pine Sales}

The sale size (acres) of individual mixed conifer and ponderosa pine sales is reasonably the same for most timbersheds. Eagar is the only exception; there ponderosa pine sales in the timbershed contain about five times more acres than mixed conifer sales. This probably occurs in the Eagar timbershed because the mixed conifer stands there tend to be of smaller acreage and scattered throughout the timbershed. However, even though the acreage of pine sales is five times larger in the Eagar timbershed, the total volume of pine sales is only twice that of the mixed conifer sales with no statistically significant difference. This is partly because mixed conifer stands have more volume per acre, resulting in a total mixed conifer sale volume much closer to the total pine sale volume. This is demonstrated also in the Alamogordo timbershed, where the additional volume per acre results in a mixed conifer sales volume that is three times larger than ponderosa pine (although not significantly different), even though the sale acreage sizes for the two species are reasonably similar. Other factors also influence the volume harvested including differences in silvicultural prescriptions.

One problem commonly associated with mixed conifer species is a high level of defect, particularly in New Mexico timbersheds. Another problem is lower lumber selling value. This too is reflected in the sale appraisal analysis, which shows mixed conifer lumber selling values (log scale) to be generally lower than ponderosa pine, and significantly lower in the Eagar and northern New Mexico timbersheds. Finally, mixed conifer sales typically have a heavier concentration of slash and added costs for lopping, piling, or scattering slash. In general, the appraisal analysis indicates some additional costs for slash disposal in mixed conifer sales, but these differences are not enough to create any marked difference in total production costs. ${ }^{8}$

${ }^{B}$ There is, however, a good deal of variation in slash disposal costs, depending on the extent of USDA Forest Service participation in slash disposal, silvicultural prescriptions, yarding unutilized material and fire hazard reduction requirements, and fuelwood markets. Thus, the variation possible may be the major problem; the mean values discussed here do not reflect this situation. Given this range in values, slash disposal costs could definitely be a major cost in certain sales. Table 2 illustrates, by the width of the confidence intervals, the variation in slash piling costs.
There are positive features related to mixed conifer utilization that tend to offset these problems. For example, compared to ponderosa pine sales, the mixed conifers sometimes have large diameters and generally have higher volume per acre. In certain cases, mixed conifer sales involve shorter hauls to the processing center. These factors can combine to help decrease overall production costs. This seems to be the case in the sales analyzed here, because total production costs are not significantly different between ponderosa pine and mixed conifer sales. The contention that total production costs are reasonably the same was supported, informally, by on-site discussions with the mill operators and Forest Service personnel at two of the processing centers. Depending on location, however, others estimated the logging costs to be $10-25 \%$ higher for mixed conifer timber. The appraisal analysis indicated that in the Fredonia and Alamogordo timbersheds, mixed conifer logging costs per thousand board feet are, in fact, about $10 \%$ higher, while the opposite is the case in Eagar and northern New Mexico timbersheds where mixed conifer logging costs are approximately 10\% less than ponderosa pine, although not significantly different.

To determine whether mixed conifer sales were less "profitable" a comparison was made of total production costs (less stumpage) to lumber selling value--the higher the percentage of total costs to selling value, the less the margin for a net return. The results of this analysis (table 2) indicated that there were no statistically significant differences between ponderosa pine and mixed conifer sales. The mixed conifer sales averaged $4 \%$ less (percentage of total costs to selling value) than ponderosa pine sales in New Mexico - 73\% compared to $77 \%$. However, the opposite occurs in the Arizona timbersheds. There, the percentage averaged about $6 \%$ higher in mixed conifer sales - 71\% compared to $65 \%$. This, in part, is related to lower lumber selling values (Eagar) as well as longer hauling distances (Fredonia) for mixed conifer sales.

Sale appraisals specifically for cable logging were not available for either mixed conifer or ponderosa pine; therefore, cost estimates were collected through informal discussions with Forest Service personnel and loggers. Loggers currently using cable systems estimate the stump-to-truck costs to be about $\$ 40$ per thousand board feet higher for cable logging. Forest Service personnel estimate these costs to be even greater $-\$ 80$ per thousand board feet higher than the costs of conventional harvest methods. In all the timbersheds, this additional cost added to the current total production costs would result in a cost figure close to, and in some cases higher than, the selling value of the lumber. This would result in little, or no margin available to the mill for profit and risk, or no return to the timberseller for stumpage. Also, this cost-to-selling value comparison does not include roads, a likely component of cable logging sales that would further reduce the margin for a return to the mill or timber seller. Given these additional costs of cable logging, some incentives or innovations must be developed to make most cable sales economically feasible. 


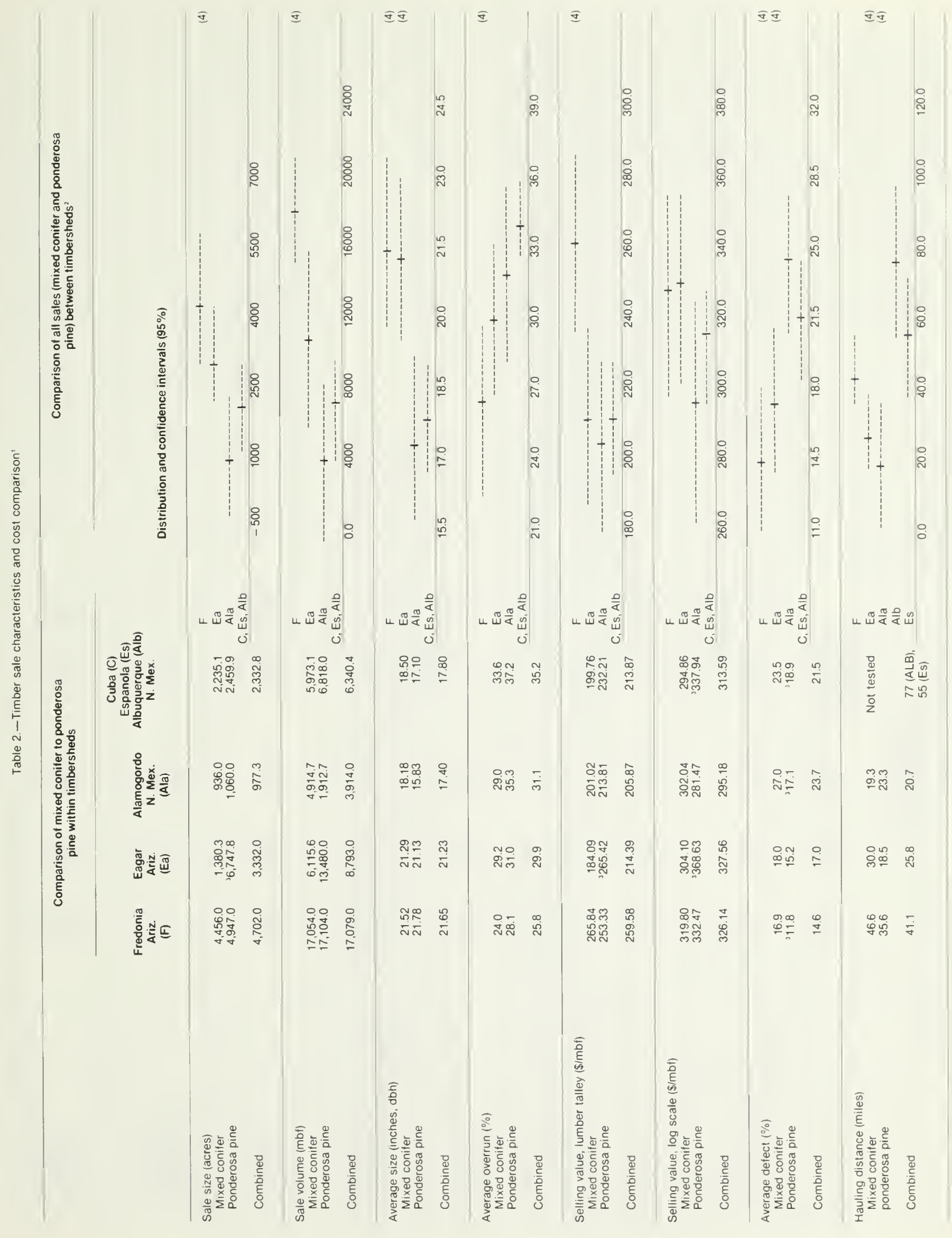




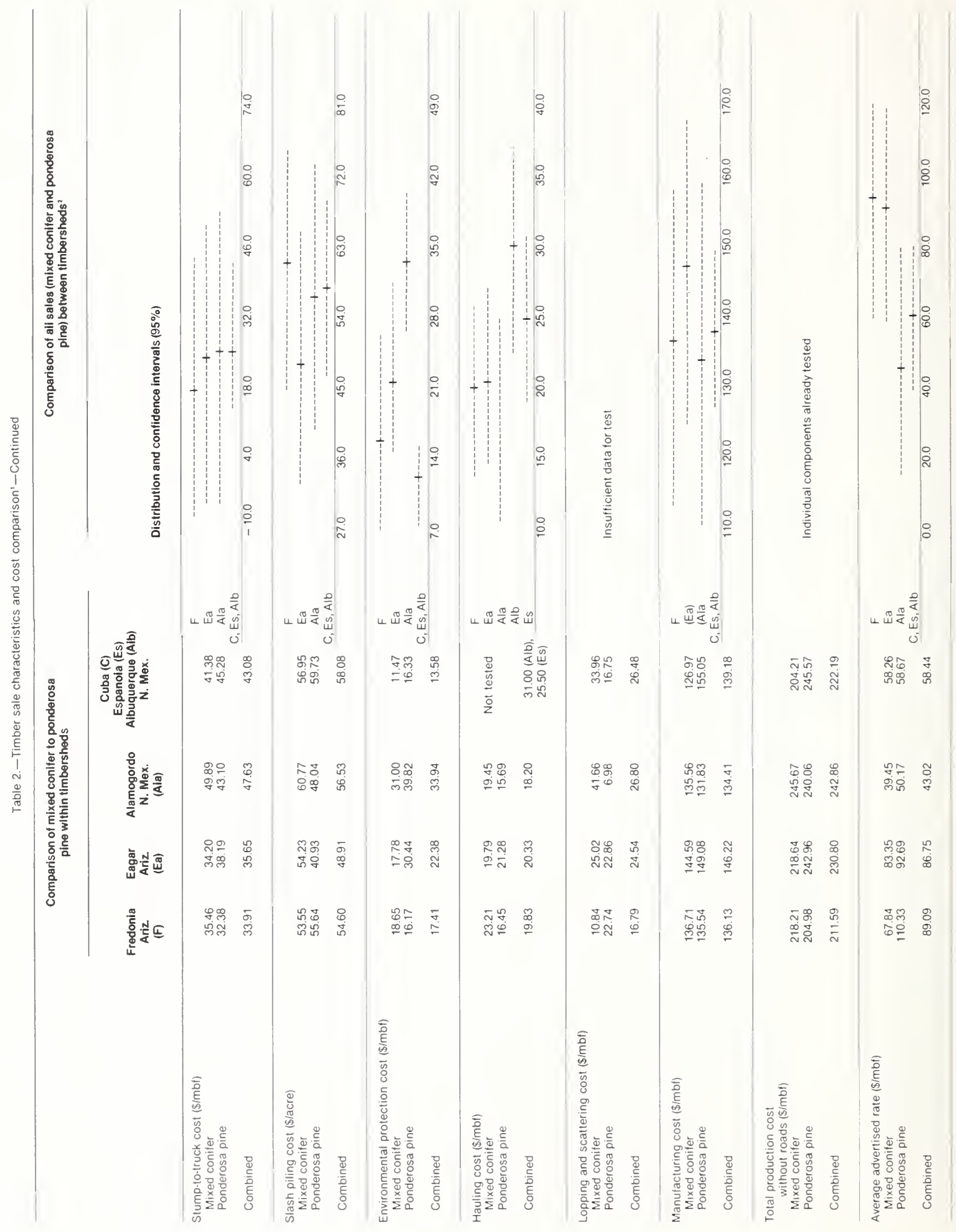




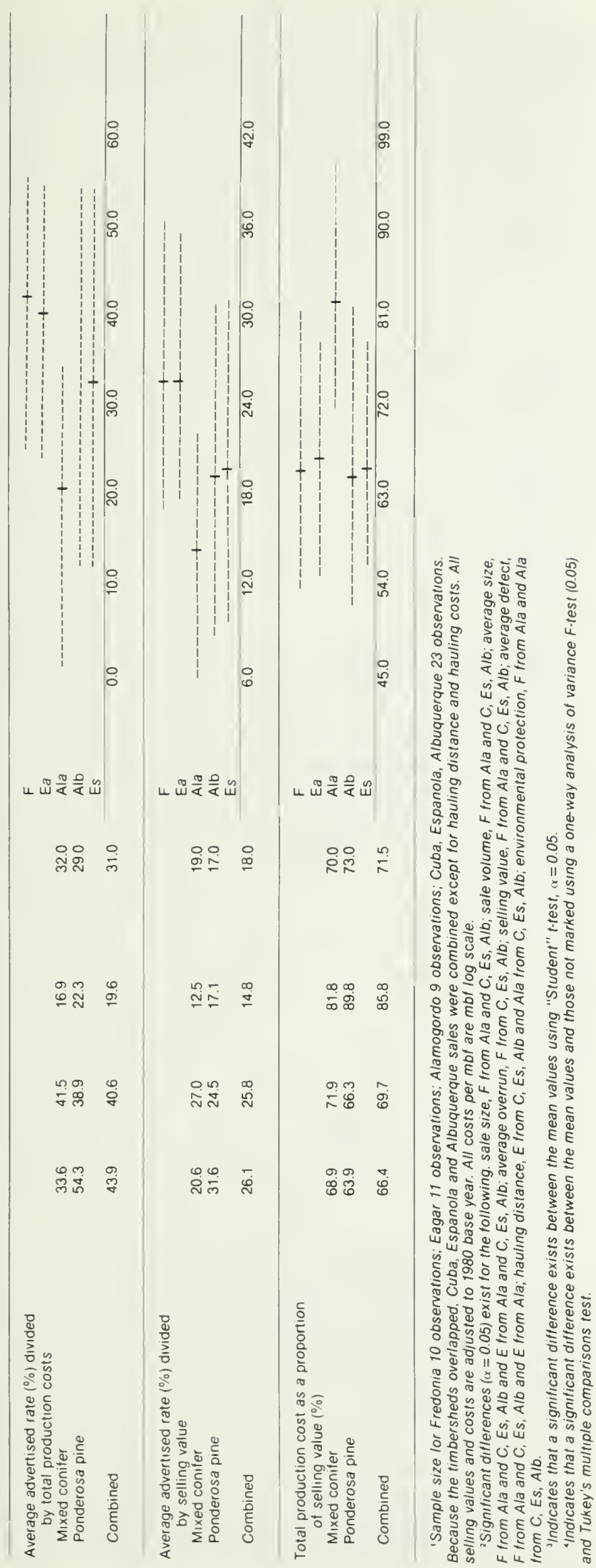

\section{Comparison of Timbersheds}

Table 2 reveals some interesting differences in the sale characteristics between the Arizona and New Mexico timbersheds. In general, the sale sizes, volumes, and timber diameter are all larger in the Arizona timbersheds; the Arizona timber also has fewer defects. Larger timber diameter and lower level of defect, for example, combine to provide for higher lumber selling values in Fredonia. Larger sale size and volumes are related, in part, to the lesser number of small business (SBA) set-asides in Arizona. Conversely, New Mexico timbersheds have more smaller acreage SBA sales. Overall, the typical wood utilization problems related to mixed conifer species seem to be less pronounced in Arizona than in the New Mexico timbersheds, and the situation in Arizona is more favorable from a lumber production/selling value standpoint.

Other sale characteristics relating to costs, such as manufacturing, slash disposal and stump-to-truck costs, do not seem to vary markedly between the timbersheds. In general, stump-to-truck, or logging costs, are about $16 \%$ of total production costs in Arizona, and about $19 \%$ in New Mexico's timbersheds. The only costs showing statistically significant differences were environmental protection costs, which were generally less expensive in the northern New Mexico timbersheds. Overall total unit costs averaged slightly less in Arizona timbersheds than in New Mexico. However, there was no statistically significant difference.

These sale characteristics combine to make the percentage of total cost to lumber selling value for both mixed conifer and ponderosa pine slightly more favorable in Arizona, averaging $68 \%$ there compared to $75 \%$ in New Mexico. Alamogordo had, by far, the least favorable situation, with costs making up $86 \%$ of selling value. None of these figures, however, were statistically different. The appraisal process compensates for the disadvantage of a lower cost-to-selling value percentage in the charge for stumpage. This process is designed to account for varying cost and price levels and to derive a fair return for the standing timber. In this case, stumpage rates charged for timber compensate for cost advantages in Arizona, and make up a larger percentage of both total cost and selling value in the Arizona timbersheds. When stumpage cost is added to the other production costs, the percentage of total cost (including stumpage) to selling value is similar in nearly all the timbersheds, about $90 \%$. These percentage figures tend to reflect favorably on the effectiveness of the residual appraisal system. But more importantly, these figures suggest that in areas where stumpage makes up a larger percentage of cost, resource managers have the best opportunity to mitigate problems related to utilization by adjusting stumpage fees. Careful prescription and appraisal preparation is necessary to make the connection between wood utilization and timber management economically feasible. In areas where the proportion of costs to selling value is high, a relatively small increase in costs in any category could have the effect of making an already "marginal" operation infeasible. 


\section{Supply Schedules}

Economic supply schedules based on costs were developed for each timbershed for ponderosa pine, mixed conifer, and the aggregate of the two timber types. These schedules are graphed in figures $2-4$ and depict the relationship between procurement costs, including hauling costs, and available sawtimber volumes in each timbershed. ${ }^{9}$ The schedules illustrate the differences between each timbershed's cost, volume, and distance characteristics, and serve to emphasize the importance of analyzing the mixed conifer supply situation on a sitespecific basis. For example, given a certain procurement cost, each timbershed's supply schedule shows a different level of volume available. The schedules' graphs also vary in terms of their steepness in slope. If the supply schedule graph is steep, or more vertical (inelastic), additional volumes may be acquired, but only with substantial increases in procurement costs, whereas if the slope is less steep, or more horizontal (elastic), additional volumes can be procured with less cost increase. ${ }^{10}$ The supply curve's slope depends on the

${ }^{9}$ Available sawtimber volumes are volumes occurring on the standard component lands. These volumes are the only figures used in the supply schedules, because the procurement costs involve conventional logging methods, which apply to standard component lands only, not to marginal lands.

${ }^{10}$ Elasticity of supply is related to the slope but is not the same thing. The elasticity concept is defined as the relationship of a percentage change in price (or cost) to the percentage change in quantity (or volume) supplied. A portion of a supply schedule is said to be elastic when a given percentage change in cost results in a greater inverse percentage change in volume supplied. Supply is inelastic when a given percentage change in costs results in a smaller inverse percentage change in quantity supplied.

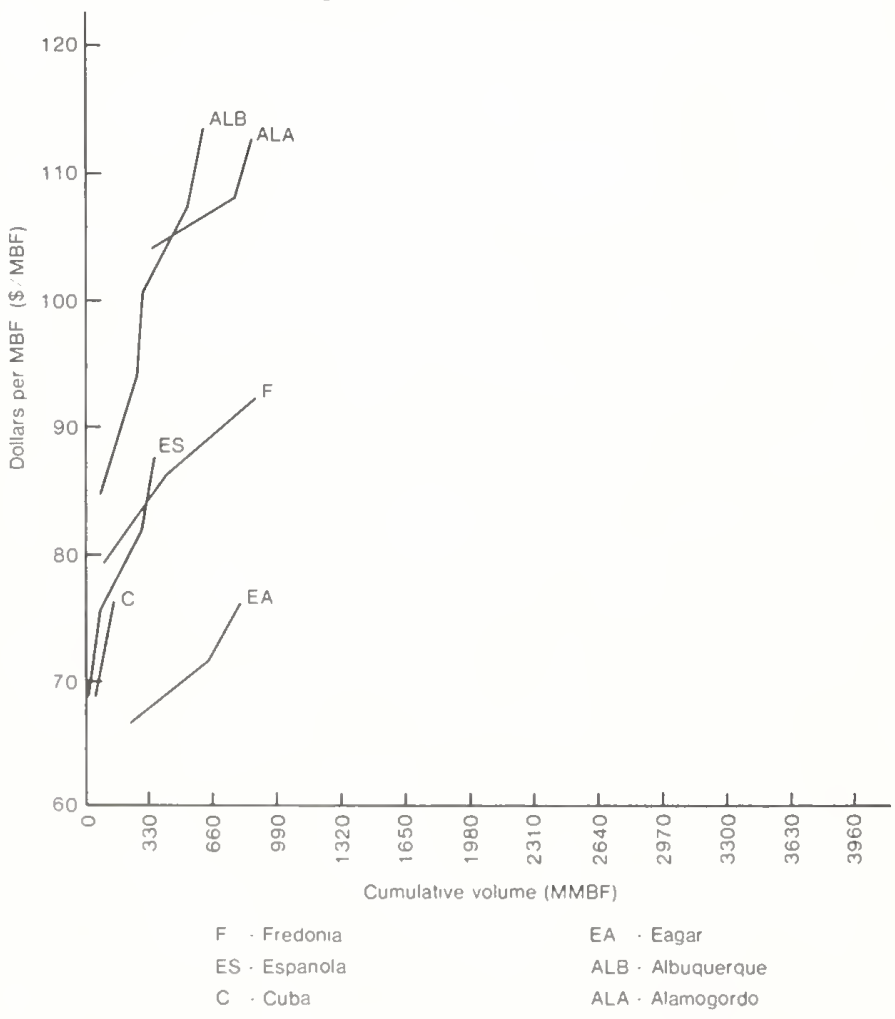

Figure 2-Mixed conifer supply schedules.

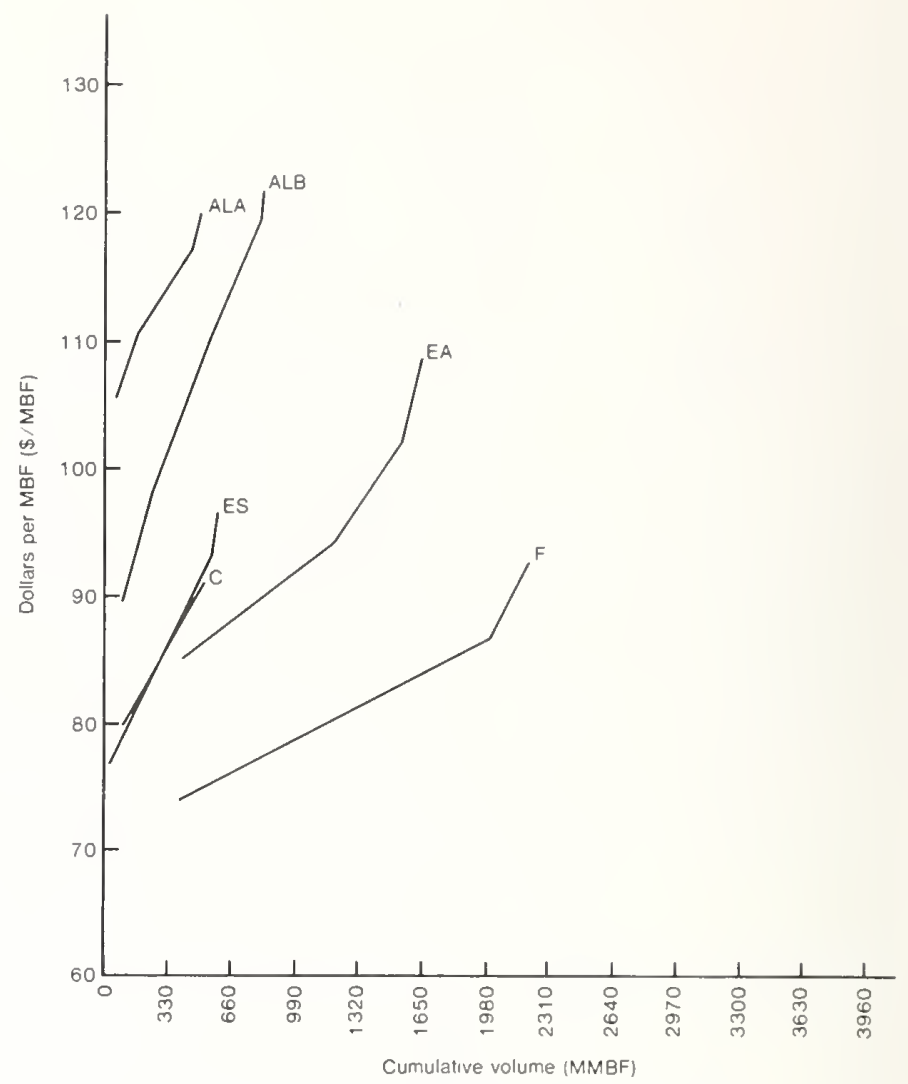

Figure 3-Ponderosa pine supply schedules.

distribution of timber volume and the location and type of roads within the timbershed; therefore, slope can vary over any portion of a supply schedule.

The timbershed supply schedules for mixed conifer and ponderosa pine all indicate an overall procurement cost advantage in the Arizona timbersheds. For example, all the available mixed conifer volume (fig. 2) and a large portion of the ponderosa pine volume (fig. 3) in the Eagar and Fredonia timbersheds can be procured at less cost per thousand board feet than the least costly volumes available in the Albuquerque and Alamogordo timbersheds. The schedules for New Mexico's timbersheds are also more inelastic than Arizona's, indicating that additional volumes are available, but only with proportionately larger increases in costs. However, this inelasticity means changes in costs (breakeven cost) will have less of an impact on total quantity procured in New Mexico and more of an impact on volumes removed in Arizona. ${ }^{11}$

Although total volumes available may be similar in certain timbersheds (e.g., the mixed conifer volume in Eagar, Fredonia and Alamogordo), their economic accessibility and, thus, availability for intensive management are quite different. For example, if a $\$ 90$ breakeven cost per thousand board feet (logs to the mill deck) for mixed conifer logs is the maximum feasible procurement cost, then the total available volume in the Espanola, Cuba, Fredonia, and Eagar timbersheds could

\footnotetext{
"These timbershed procurement costs are based on the average costs by timbershed. Therefore, they should reflect the harvesting conditions of the timbershed and the operational efficiency that exists in each separate case, given the appraisal data.
} 
be economically procured and be part of a timber management/wood utilization program. However, little or no mixed conifer volumes would be economically available at $\$ 90$ per thousand board feet in the Albuquerque and Alamogordo timbersheds. These timbersheds could not be managed as part of such an intensive timber management program. Different breakeven costs per thousand board feet could be used with the supply schedule to assess their impacts on the procurement situation. The ponderosa pine/mixed conifer volume mix economically available would vary by timbershed, depending on the amount of this breakeven cost.

The supply schedules indicate that mixed conifer offers procurement cost advantages over ponderosa pine in Eagar, Alamogordo, and Cuba timbersheds. Mixed conifer is generally closer to the processing centers in these timbersheds. In the Espanola and Albuquerque timbersheds, the mixed conifer costs are generally the same as those for ponderosa pine. The only timbershed where ponderosa pine is cheaper to procure is Fredonia, where the ponderosa pine is closer to the processing center. Overall, from a procurement cost standpoint, mixed conifer sales are similar to ponderosa pine at most processing centers.

The overall timber supply situation for the timbersheds is shown in figure 4. Aggregating mixed conifers and ponderosa pine volumes changes the supply schedules dramatically, because each timber type's procurement cost per thousand board feet and volume location vary considerably within the timbershed. Figure 4 illustrates the overall cost advantage of the Arizona timbersheds and the additional available or operable volumes located there. For example, for any given procurement

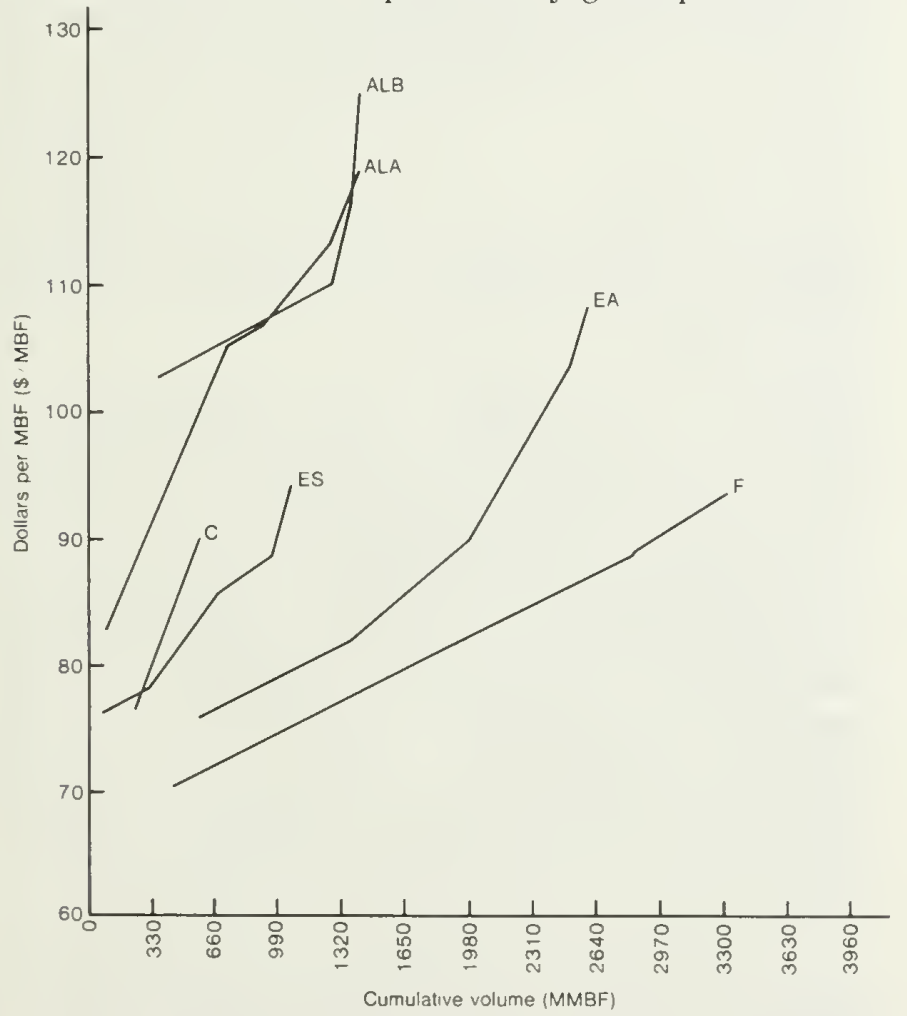

Figure 4-Combined ponderosa pine and mixed conifer supply schedules. or break-even cost, more volume can be procured in the Arizona timbersheds. Fredonia and Cuba's supply schedules are almost linear, indicating a fairly uniform distribution of the aggregated timber volumes over the timbershed. Alamogordo and Albuquerque timbersheds have the least favorable procurement situation. They have higher overall procurement costs which rise rapidly for small increases in additional volumes. Decreases in lumber selling values or increases in production costs are likely to have more of an impact there, and to make intensive timber management more difficult economically in those timbersheds.

Figure 5 shows the relationship between procurement cost and distance in each timbershed. Albuquerque has the longest hauling distance; in fact, Albuquerque's hauling cost at 90 miles distance is close to the total procurement cost, logging plus hauling, in certain other timbersheds. The remaining timbersheds have similar hauling distances, but the distance for a specific breakeven cost varies markedly by timbershed. For example, again using $\$ 90$ per thousand board feet as a breakeven cost, hauls in the Cuba timbershed would be about 30 miles distant from the processing center, but Albuquerque's would be 60 miles. This is primarily because of the road systems involved; Cuba has a much poorer road system, which results in higher haul costs even though the haul distance is rather short; whereas Albuquerque has an excellent road system, including a large portion of interstate roads. Generally, Cuba, Espanola, Fredonia and Eagar have similar supply schedules for cost versus distance. Alamogordo has a similar range in distances, but much higher costs per thousand board feet. Albuquerque has much longer hauls, and, therefore, greater overall costs per thousand board feet.

The different volumes available at various distances cause the slopes of individual supply schedules to change over the range of available volumes. For example, in figure 5 , the slope of the supply schedule for mixed conifers at Fredonia first rises rapidly but then increases at a lesser rate for additional volumes. This is because most mixed conifer is further away, and in a particular distance zone (40-60 miles haul), much more volume is available. In this distance zone, total costs of procurement are spread out over more volume. Therefore, the incremental increase in procurement costs per thousand board feet become less, decreasing the slope. A similar explanation applies to cases where the curve shifts upward. However, in this case the volumes are declining, and total costs must be spread over less volume. Therefore, the marginal or incremental cost per thousand board feet increases. Many of the supply schedules increase in slope near the boundaries of the timbershed, where timber volumes tend to decline.

The fact that this rate of increase in marginal costs or costs per thousand board feet changes over the span of volumes available and over distance from the processing center illustrates an interesting phenomenon often overlooked in timber supply economics. Sales which are further from the processing center are likely to have higher procurement costs; but for a given increment in volume or distance, they are not likely to have the same 
rate of increase. This creates situations where procurement costs do not rise markedly over a given range of haul distances. For example, procurement costs for Albuquerque are not much different over an 80 - to 100-mile interval in hauling distance. Although the magnitude of this phenomenon varies, it also occurs at various points in the timbersheds: $30-45$ miles in Espanola; 40-50 miles in Fredonia; 40-60 miles in Eagar; 30-35 miles in Alamogordo (fig. 5). These distance zones indicate areas where intensive timber management and wood utilization may be relatively more feasible from a procurement cost standpoint.

\section{PRODUCTS ${ }^{12}$}

Traditionally, the principal wood products produced in Arizona and New Mexico have been structural type products, such as kiln- or air-dried dimension lumber and boards used in residential and industrial construction. Housing construction, in particular, has been a major market outlet for the lumber produced in the two states. However, during the past few years, the reduced housing market has contributed to decreased production. Coping with a poor housing market requires, in part, considering production of additional products that have other markets and more diversified end uses. Deciding whether a new product is profitable to produce depends on numerous criteria, including the capital investment required, market location and size, as well as the technical suitability of the available raw material.

${ }^{12}$ This discussion relies heavily on written material in an addendum to the final report for this project prepared by Craig E. Shuler, wood technologist, Colorado State University entitled, "Technical Suitability of Product Development from Mixed Conifer in Arizona and New Mexico" $12 \mathrm{p}$.

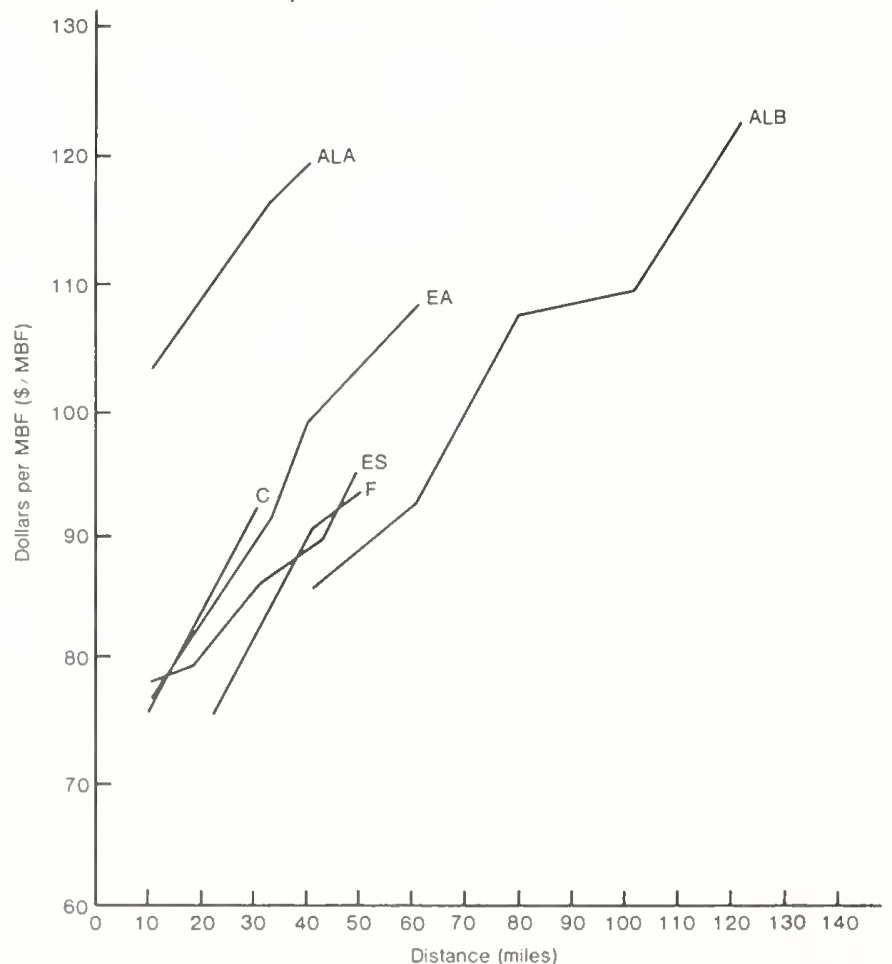

Figure 5-Variation of total procurement cost with distance for combined ponderosa pine and mixed conifer.
One of the major species of the mixed conifer type is Douglas-fir, which has greater strength properties than other species of the mixed conifer type. Therefore, it is the best suited of the mixed conifer species for structural applications and has been commonly used to produce dimension lumber for framing buildings. Another structural application which might expand this market would be manufacture of machine-rated lumber for use in trusses or concrete formwork. Additionally, the hardness of Douglas-fir could be used to advantage in development of flooring, either the typical tongue-andgroove material or patterned parquet-style "tiles." Various types of sawn timbers also offer possibilities. Timbers typically have diversified end uses, including railroad ties, decorative beams, decking, guardrail supports and mining and landscaping usếs. These timbers also could be laminated such that only highly stressed regions of the member need higher quality or strength. Thus, species with lower strength ratings, such as Engelmann spruce, might also be used. Laminated dimension lumber for joists or planking might be manufactured from smaller size Douglas-fir logs as well as smaller logs of other species. Douglas-fir is also well suited for furniture framing, such as for waterbeds (a large, expanding industry), where high strength requirements are necessary. Finally, the species is technically suited for blocking material used to stabilize and steady truck and rail loads. Blocking material can generally be produced with basic sawmill equipment, although certain special cut-up saws may be required to shape blocking supports for items such as tanks and pipe.

White fir and ponderosa pine are lighter and generally not as strong as Douglas-fir, but have other favorable characteristics such as uniform to moderate texture, low shrinkage, ease in machinability, and ready acceptance of preservative treatments. Given these characteristics, these species can be used to produce shop lumber for remanufacture into speciality products, such as moulding, furniture stock, picture, door and window frames, and precut do-it-yourself kits. This additional processing results in considerable value added to the product line.

Pine is especially well suited for posts and poles, because it is easily treated with preservatives. Additionally, post and pole production is advantageous, because these products can be produced from smaller size logs which are less suitable for lumber. The uses of posts and poles are numerous and provide a wide range of market opportunities in ranching, urban decorative fencing, and housing (viga poles). Shakes and shingles have fairly low production costs and could have large local markets, particularly if they are treated with a fire retardant and preservative. Although pine does not have the natural resistance to decay as do some other species, this would not be of major importance for wood shingles applied locally in the dry conditions of the Southwest. Finally, solid wood siding is becoming more commonly used in housing designs. With some adjustment in sawing and planning patterns, most existing mills could use pine to satisfactorily produce this type of product. 
Quaking aspen, for various reasons, has not been used extensively for producing wood products. However, its characteristics as a hardwood have gained considerable acceptance for producing pallet material. Aspen also has been the raw material for shingles, paneling, excelsior and specialized products such as matchsticks. All of these products can be produced at a fairly low cost and their production could probably be expanded. Pulp is also a possibility although there seems to be an adequate supply of preferred softwoods to satisfy the existing market.

All the mixed conifer species mentioned could be used for fuelwood; however, the present economic return for fuelwood is fairly small compared to that for wood products, such as graded lumber. In certain cases, particularly for mills near major population centers, poorer quality or smaller-sized material might be sold at the logging site, or at the mill and provide a profitable operation. Mills not wishing to sell fuelwood at retail could sell to commercial fuelwood vendors.

The products mentioned represent possibilities for wood products mills to expand the utilization of the mixed conifer species and, at the same time, reduce their reliance on the housing market. Most of the products would not result in "high volume" operations when compared to the levels expected for structural dimension and board products now manufactured. Instead, they would allow for limited production of items serving more diverse, specialized markets. As such, successful production of these wood products and improved utilization of a variety of mixed conifer species and log sizes would require establishing a comprehensive marketing and distribution system. At the mill, more carefu. grading, sorting, and sawing practices would also be necessary to produce different combinations of products.

\section{MARKETS}

Arizona and New Mexico mills could sell the wood products mentioned in the previous section in the same prime marketing areas they now serve. These areas include the two states themselves; the south-central states including Kansas, Oklahoma, and Texas; southern California; Colorado; and the midwest portion of the United States, including Illinois and Wisconsin. Within these states, there are large metropolitan growth centers that have a strong market demand for wood products. This is emphasized by U.S. Bureau of Census Construction reports which show Illinois, Texas, Colorado, and Arizona as among the top 10 lumber-consuming states. These markets are generally closer to Arizona and New Mexico producers than to producers in other western states and, in some cases, the southern softwood lumber-producing region. Tapping the market potential in these areas would require a more comprehensive marketing and sales effort to develop closer ties and better communication with builders, wholesalers, contractors, designers, and secondary manufacturers at the marketplace.

As was the case with timber procurement, certain processing centers have marketing cost advantages over others. In the case of markets, each processing center has different shipping costs to each major market area. Shipping cost advantages are particularly important to consider, because shipping charges are likely to increase as transportation costs, in general, continue to rise. To quantify this advantage for markets outside the two states, truck freight charges (for Arizona and New Mexico mills truck rates are generally the cheapest mode of transportation) were calculated for shipping from each processing center to seven market centers in the prime market areas: Chicago, Ill.; Denver, Colo.; Dallas and El Paso, Tex.; Oklahoma City, Okla.; Kansas City, Kans.; and Los Angeles, Calif. After comparing these truck freight charges, it was clear that New Mexico's processing centers had, in most cases, shipping cost advantages over the Arizona mills, ranging from about $\$ 10$ to $\$ 20$ per thousand board feet less. The only market center where Arizona mills had a shipping cost advantage was the Los Angeles market.

Given the processing centers and markets considered here, Alamogordo has the best overall advantage in terms of freight rates. This processing center has a fairly unique location in southeastern New Mexico, which allows a shipping cost advantage to the large Texas markets, as well as a close local market at Albuquerque. Alamogordo also has the same freight rates as other processing centers to markets in Colorado, as well as markets in the south-central and midwestern states.

Fredonia has the highest transport costs to its markets. This processing center is fairly isolated and some distance from most of the major market centers, except Los Angeles and the local market in Phoenix. Eagar is in a somewhat better location, because it is midway between two major local markets in Phoenix and Albuquerque and is somewhat closer than Fredonia to most of the other market centers. The remaining processing centers - Albuquerque, Espanola and Cuba rank between Alamogordo and the Arizona mills in terms of freight cost advantage.

Unlike the timber supply situation where their procurement costs were greater, Alamogordo and Albuquerque processing centers seem to have cost advantages in terms of shipping products to prime market areas. This probably helps compensate for the less favorable timber supply situation and allows for a profitable operation, even though their total production costs are more than some other processing centers. These New Mexico processing centers probably can be more competitive in the market, and possibly may have a better opportunity to expand markets for traditional or new products. The production of new products is particularly important to these processing centers, because their timbersheds have both a large diversity in species available and generally smaller timber sizes that are not always suitable for traditional lumber products.

Transportation cost to market is not the only factor determining market profitability. Also critical is the product value at the market center. This product value is a function of each individual market center's supply and demand situation which can vary considerably among markets. 
An analysis of wood product wholesale prices was made for representative lumber types at each market center. The results of this analysis indicated that lumber prices at Chicago, Denver, and Dallas were generally much higher than those in the other market centers. Prices quoted at these areas ranged from about $\$ 50$ to $\$ 240$ per thousand board feet higher than the other market centers. Generally, higher product quality brought larger price differences between centers.

Although a number of factors influence market potential, other things being equal, it seems that the product values indicate that the Chicago, Denver, and Dallas market centers are best for Arizona and New Mexico producers. Products produced from mixed conifer, as well as other species, would receive the greatest net return in these markets. Higher-valued products in particular, should be sent to these market centers. Lowervalued products would probably only be profitable if sold in nearby markets.

Given information about freight rates and lumber price at the market, it appears that New Mexico mills have an advantage over Arizona mills. Although Arizona mills would also find these same markets to be the most profitable, their shipping costs would generally be about $\$ 20$ per thousand board feet more (in the case of shipping to Dallas and Chicago) than New Mexico mills. ${ }^{13}$

The overall comparative advantage of Southwest mills over certain other western states should be emphasized in any wood utilization program, particularly with wood products which already have lower selling values, such as some of the traditional mixed conifer products. Processing centers in both Arizona and New

\footnotetext{
${ }^{13}$ The differences in lumber prices $(\$ 50-\$ 250)$ at the market centers are larger than the differences in the processing centers' freight cosis (\$10-\$20). Thus, all processing centers would find it profitable to market in these areas, although some might find it more profitable than others. Additionally, the shipping cost may not be paid by the mill, because some lumber is purchased f.o.b. the mill by wholesalers. However, the value f.o.b. the mill is influenced by selling value at the market less freight costs. Therefore, the same markets as mentioned earlier should be the most profitable, even if the mills did not pay shipping charges directly.
}

Mexico have unique opportunities in the growing market of the Southwest. Their comparative advantage in this market in terms of shipping costs will probably increase in the future. Wood products firms need to plan now to develop strategies to meet this expanding local market as well as selected markets in other states.

\section{LITERATURE CITED}

Green, Alan W. and Theodore S. Setzer. 1974. The Rocky Mountain timber situation, 1970. USDA Forest Service Research Paper INT-10, 78 p. Intermountain Forest and Range Experiment Station, Ogden, Utah.

Jones, John R. 1974. Silviculture of southwestern mixed conifers and aspen: The status of our knowledge. USDA Forest Service Research Paper RM-122, 44 p. Rocky Mountain Forest and Range Experiment Station, Fort. Collins, Colo.

Moir, William H. and John A. Ludwig. 1979. A classification of spruce-fir and mixed conifer habitat types of Arizona and New Mexico. USDA Forest Service Research Paper RM-207, 47 p. Rocky Mountain Forest and Range Experiment Station, Fort Collins, Colo.

Primary Wood Industries of Arizona. 1978. Arizona Land Marks, Vol. 8, Book 5, 11 p. Arizona State Land Department, Phoenix.

Setzer, Theodore S. and Michael K. Barrett. 1977. New Mexico timber production and mill residues, 1974. USDA Forest Service Research Note INT-231, 6 p. Intermountain Forest and Range Experiment Station, Ogden, Utah.

Setzer, Theodore S. and Terrence S. Throssell. 1977. Arizona timber production and mill residues, 1974. USDA Forest Service Research Note INT-230, 6 p. Intermountain Forest and Range Experiment Station, Ogden, Utah.

Western Wood Production Association. 1980. Statistical yearbook of the western lumber industry. 33 p. Western Wood Products Association, Portland, Ore.

Wood Industry of New Mexico. 1979. New Mexico Division of State Forestry, Santa Fe. 25 p. 


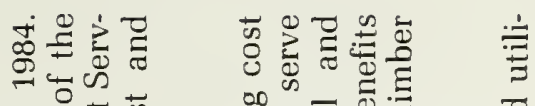

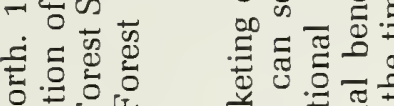

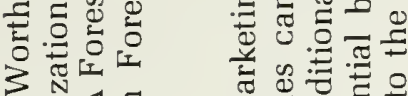

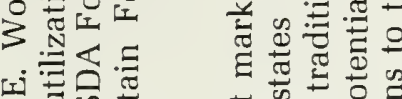

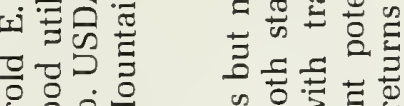

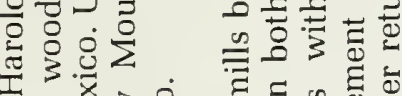

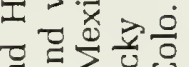

다인

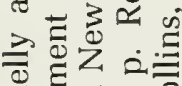

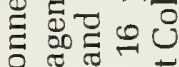

苋苋依

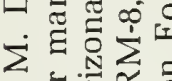

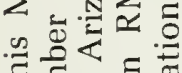

范范焉

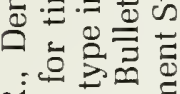

$\simeq$ के

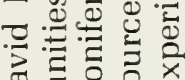

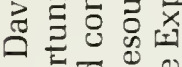

w

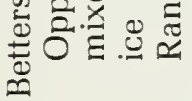

范.

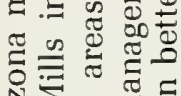

을 元.

的离南离

흘 豆

雨

象.

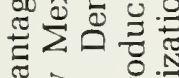

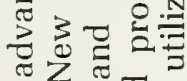

की

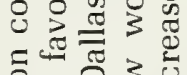

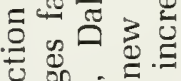

导焉品

之胥.

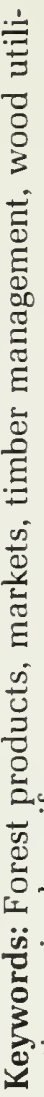

遇总

¿

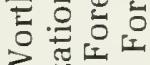

3 恣约

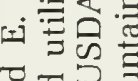

끙용

刃 3.0

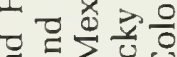

징

를

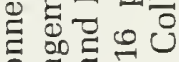

을 范

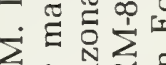

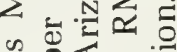

㽞

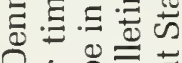

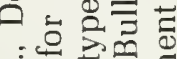

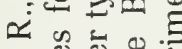

곡

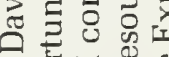

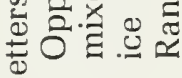

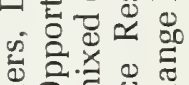

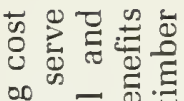

.

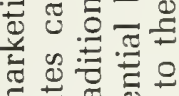

要焉焉要

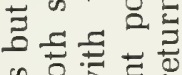
으을 흥

ह. $\Xi$ 焉

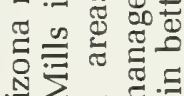

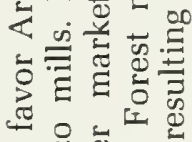

\&.

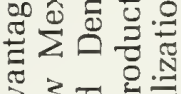

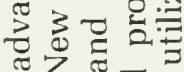

के के क्षे

恶

要

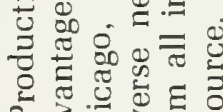

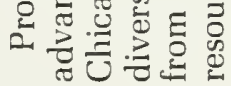

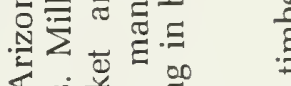

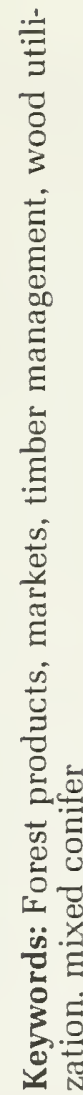

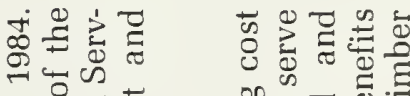

도웛

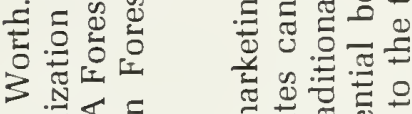

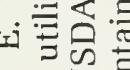

듬돜

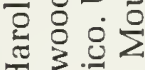

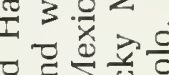

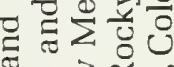

궁

导品

䠑 0

$\stackrel{\widetilde{\pi}}{\mathrm{\pi}} \stackrel{\pi}{*} \infty^{\circ}$

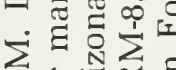

$\sum-N \sum \dot{0}$

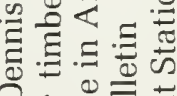

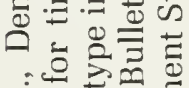

$\sim \underset{\sim}{\Xi}$

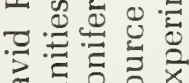

刃

-

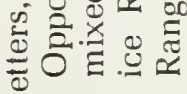

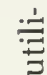

ב

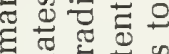

类士

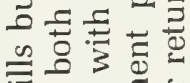

घ्घ क छ छ

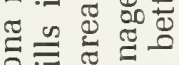

옳 ฮ

赔离品

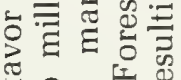

必过 d

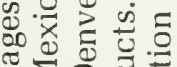

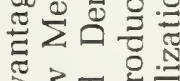

总总范总

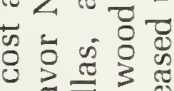

표류

邑方怘

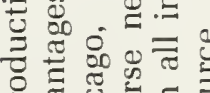

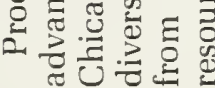

苞

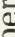

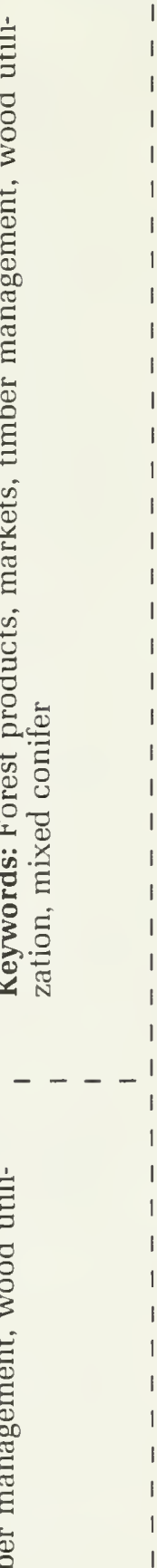

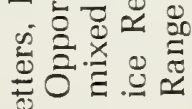

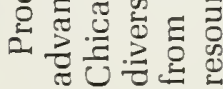
$\infty$ 




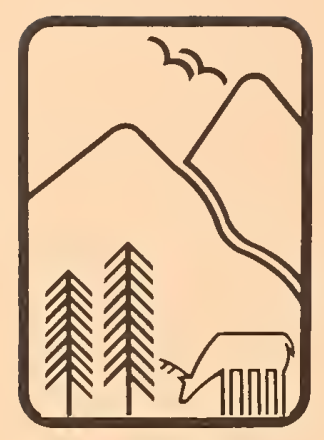

Rocky
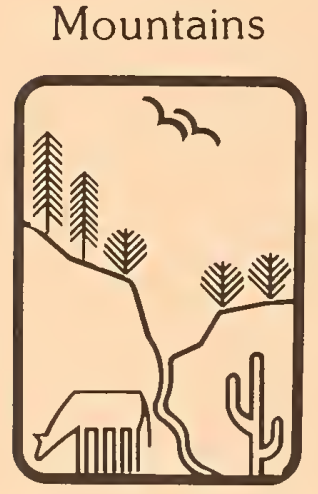

Southwest

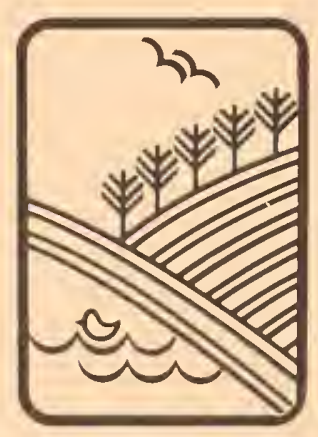

Great

Plains
U.S. Department of Agriculture Forest Service

\section{Rocky Mountain Forest and Range Experiment Station}

The Rocky Mountain Station is one of eight regional experiment stations, plus the Forest Products Laboratory and the Washington Office Staff, that make up the Forest Service research organization.

\section{RESEARCH FOCUS}

Research programs at the Rocky Mountain Station are coordinated with area universities and with other institutions. Many studies are conducted on a cooperative basis to accelerate solutions to problems involving range, water, wildlife and fish habitat, human and community development, timber, recreation, protection, and multiresource evaluation.

\section{RESEARCH LOCATIONS}

Research Work Units of the Rocky Mountain Station are operated in cooperation with universities in the following cities:

Albuquerque, New Mexico

Flagstaff, Arizona

Fort Collins, Colorado*

Laramie, Wyoming

Lincoln, Nebraska

Rapid City, South Dakota

Tempe, Arizona

-Station Headquarters: 240 W. Prospect St., Fort Collins, CO 80526 